\title{
Atbilstības novērtēšanas elementi: saistītie jēdzieni, to pilnveide
}

\author{
Raimonda Liepiṇa ${ }^{1}$, Jānis Mazais ${ }^{2}$, Inga Lapiṇa ${ }^{3},{ }^{1-3}$ Rĭgas Tehniskā universitāte
}

\begin{abstract}
Kopsavilkums. Veicot atbilstības novērtēšanas jomas izpēti, autori ir identificējuši atšksirīgu terminu un definīciju pielietojumu. Pētījuma mērķis ir novērtēt ar atbilstības novērtěšanu saistītos terminus un pilnveidot definīcijas, lai izveidotu vienotu terminolog̣ijas kopumu latviešu valodā. Analīzē ir izmantotas kvalitatīvās pētījuma metodes. Pētījuma noslēgumā autori ierosina vairāku terminu precizētus formulējumus un pilnveidotas definīcijas. Precizējot un pilnveidojot terminoloğijas bāzi, tiks veidota un attīstīta dažādu iesaistīto pušu izpratne par atbilstības novērtēšanas jomu.
\end{abstract}

Atslēgas vārdi: akreditācija, atbilstības novērtēšana, metroloğija, standartizācija.

\section{IEVADS}

Atbilstîbas novērtēšana ir būtisks priekšnosacījums Eiropas Savienības (ES) vienotā tirgus darbības sekmīgai nodrošināšanai. Pamatojoties uz veikto novērtējumu, produkti tiek atzīti par atbilstošiem prasībām, un tos var ievietot ES teritorijā, brīvi pārvietot tajā un nodot lietošanā patērētājiem.

Lai izprastu, izpildītu un nodrošinātu prasības par atbilstoša produkta ievietošanu tirgū, jāpārzina ar atbilstības novērtēšanu saistīiā terminolog̣ija un definīcijas. Sadarbībā ar nozares pārstāvjiem, autori identificējuši atšķirīgu terminu un definīciju pielietošanu praksē. Konstatēts, ka ne visiem angl̦u valodas terminiem tiek lietoti atbilstoši tulkojumi latviešu valodā un ka atbilstības novērtēšanas terminu definējumi dažādos literatūras avotos, normatīvajos aktos u.c. dokumentos atšksiras.

Autori uzskata, ka vienota un viennozīmīga izpratne par saistošajiem terminiem un definīcijām ir būtisks priekšnoteikums korektu un atbilstošu atbilstības novērtēšanas darbību veikšanai. Pretējā gadījumā pastāv risks, ka iesaistītās puses dažādi uztvers un interpretēs nosacījumus, kā rezultātā rīkosies neatbilstoši noteiktajām prasībām. Tas var izraisīit arī noteiktas sekas - neatbilstošu produktu ievietošanu tirgū.

Pētījuma mērķis ir novērtēt ar atbilstības novērtēšanu saistītos terminus un pilnveidot definīcijas, lai izveidotu vienotu terminologijas kopumu latviešu valodā.

Galvenokārt izmantotas kvalitatīvās pētījuma metodes, t.sk. novērtēšana, analīze un salīdzināšana, pielietojot gan indukciju, gan dedukciju.

Autoru darba rezultātā tiek pilnveidotas terminu: atbilstība, novērtēšana, atbilstības novērtēšana, atbilstības novērtēšanas procedūra, paziņotā institūcija, standartizācija un piemērojamais standarts definīcijas un precizēts terminu paziñotā institūcija un piemērojamais standarts tulkojums latviešu valodā, kā arī pamatots termina mērī̌sanas lìdzeklis pielietojums.

Precizējot un pilnveidojot terminologiijas bāzi, tiks veidota un attīstīta dažādu iesaistīto pušu izpratne par atbilstības novērtēšanas jomu. Tas ir būtisks faktors savstarpējās sadarbības veicināšanā un patērētājam drošas uzṇēmējdarbības vides attīstī̌sanā Latvijā.

\section{JĒDZIENS 'ATBILSTĪBAS NOVĒRTĒŠANA'}

Lai objektīvi izvērtētu jēdzienu 'atbilstības novērtēšana', autori sākotnēji izvērtējuši katru no jēdzienā ietvertajiem terminiem - 'atbilstība' un 'novērtēšana' - atseviškiki.

Jēdziens 'atbilstība'

Autori izpētīja dažādu autoru viedokḷus par jēdzienu 'atbilstība' un ar to saistîtos terminus un attēloja to kopsakarības shēmu (skat. 1.attēlu).

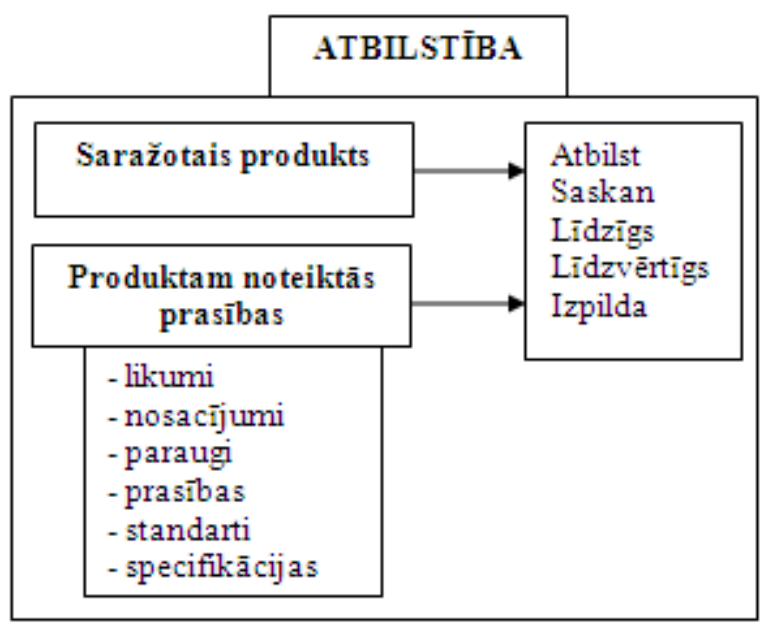

1.att. Ar jēdzienu 'atbilstība' saistīto terminu kopsakarības shēma.

Izvērtējuma rezultātā secināts, ka ar jēdzienu 'atbilstība' pēc būtības saprot divu lielumu salīdzināšanu. Produkta gadījumā saražotais produkts tiek salīdzināts ar tam sākotnēji noteiktajām prasībām. Prasības produktam var noteikt gan valsts institūcijas, gan klienti, gan pats ražotājs. Tās var būt obligātas (noteiktas normatīvajos aktos, standartos, specifikācijās, instrukcijās u.c.) un neobligātas, t.i., rekomendējošas.

İpašība, kas apliecina atbilstību, var izpausties kā produkta un prasību saskanīgums, līdzịgums, līdzvērtīgums vai izpildījums. Atbilstības galvenā pazīme - vai gala rezultāts atbilst sākotnējām prasībām, nevis pakāpe, kādā atbilstība tiek konstatēta.

Lielākā daļa termina 'atbilstība' definīciju un apgalvojumi par to ir nekonkrēti un pielietojami vispārīgi. Piemēram, J.R.Evans un V.M.Lindsejs terminu 'atbilstība' skaidrojuši kā „,pakāpi, kādā produkta fizikālie un izpildījuma raksturlielumi 
saskan ar iepriekš noteiktiem standartiem [1]". Uzñēmējdarbības loǵistikas terminu Angḷu - latviešu vārdnīcā termins 'atbilstība' definēts šādi: „Atbilstība ir visu klientu noteikto prasību izpilde attiecībā uz izstrādājumu, procesu vai pakalpojumu [2]". Autori uzskata, ka šie definējumi nav pielāgoti atbilstības novērtēšanas jomas specifikai un pilnībā neaptver 1.attēlā atspoguloto kopsakarības shēmu.

Angḷu - latviešu starptautiskajā biznesa vārdnīcā ietvertā defin̄icija: „Atbilstība - apstiprinājums (apliecinājums) par (preču, pakalpojumu u.tml.) atbilstību prasībām [3]" visprecīzāk raksturo jēdziena 'atbilstība' būtību kontekstā ar atbilstības novērtēšanas jomu. Tomēr autori šo definīciju uzskata par nepiln̄̄gu, jo tā vairāk raksturo rīcību pēc atbilstības konstatācijas, kad tiek izsniegts faktisks apliecinājums (ar to saprotot dokumentāru apstiprinājumu). Atbilstība ir fakta konstatācija, salīdzinot objektu ar tam noteiktajām prasībām. Piemēram, produktu gadījumā objekts ir saražotais produkts un obligātās prasības tam noteiktas normatīvajos aktos.

Pêtījuma par atbilstības novērtēšanu kontekstā autori ierosina skaidrot terminu 'atbilstība' šādi: „Atbilstība ir fakts, ka objekts (produkts, process u.c.) izpilda tam noteiktās prasības."

\section{Jēdziens 'novērtēšana'}

Izvērtējot jēdzienu 'novērtēšana', autori secina, ka novērtēšana pēc būtības ir process, kurā veicamās darbības var būt noteikšana, vērtēšana, aprēksināšana, mērīšana. Balstoties uz šo darbību rezultātiem, iespējams pieņemt lēmumu. Atbilstības novērtēšanas jomā tiek novērtēts, vai objekts atbilst vai neatbilst tam sākotnēji izvirzītajām prasībām.

Longman Dictionary of Contemporary English ietvertā definīcija: "Novērtēšana ir process, kurā tiek veikts vērtējums par personu vai situāciju, vai pašu vērtēšanu," [5] visprecīzāk raksturo darbības, kas tiek darītas, veicot objekta atbilstības novērtēšanu. Autori uzskata, ka novērtēšanai jābūt orientētai uz noteiktu galarezultātu - lai tiktu piensemts lēmums, un ierosina skaidrot termina 'novērtěšana' šādi: „Novērtēšana ir process, kurā nosaka objekta (produkta, procesa u.c.) saskaņu ar tam noteiktajām prasībām.”.

No veiktā jēdzienu 'atbilstība' un 'novērtēšana' izvērtējuma izriet, ka 'novērtēšana' ir salīdzināšanas process, kura ietvaros novērtē objekta atbilstību konkrētām prasībām. Savukārt, 'atbilstība' ir fakta konstatācija par objektam noteikto prasību izpildi. Tādējādi 'atbilstības novērtēšanas' ietvaros tiek salīizināts objekts ar tam noteiktajām prasībām un konstatēta to atbilstība vai neatbilstība.

Lai vispusīgi veiktu jēdziena 'atbilstības novērtēšana' izvērtējumu, tika salīdzinātas dažādos literatūras avotos (vārdnīcās, grāmatās un zinātniskajās publikācijas) ietvertās definīcijas un autoru viedokḷi.

Jēdzieni 'atbilstības novērtēšana' un 'atbilstības novērtēšanas procedūra'

ES atbilstības novērtēšanas jomā šobrīd par noteicošo tiek uzskatīta ES normatīvajos aktos noteiktā definīcija: „Atbilstības novērtēšana ir process, kurā novērtē, vai ir ievērotas ar produktu, procesu, pakalpojumu, personu vai struktūru saistītās prasības [6]". Š̄ definīcija ir balstīta uz standartā LVS EN ISO/IEC 17000: 2005 „Atbilstības novērtēšana - Vārdnīca un vispārīgie principi” ietverto definīciju [7]. Atbilstoši minētajām definīcijām tiek uzskatīts, ka atbilstības novērtēšana ir process, kurā novērtē, vai ir izpildītas produktam noteiktās prasības.

Autori minētās un tām līdzīgās definīcijas uzskata par daḷēji atbilstošām, jo tās ir l̦oti vispārīgas un tajās nav konkretizēts, kādā veidā tiek veikta atbilstības novērtēšana, kā arī nav norādes par darbībām, kas seko pēc atbilstības novērtēšanas (produkta markēěšana).

Pamatojoties uz veikto jēdziena 'atbilstības novērtēšana' definīciju izvērtējumu, autori attēlojuši saistīto terminu kopsakarības shēmu (skat. 2.attēlu). Kopsakarības shēma veidota, secīgi grupējot terminus, kas apzīmē viena veida darbību, un izcel̦ot tos terminus, kas visatbilstošāk atspoguḷo konkrēto jēdzienu.

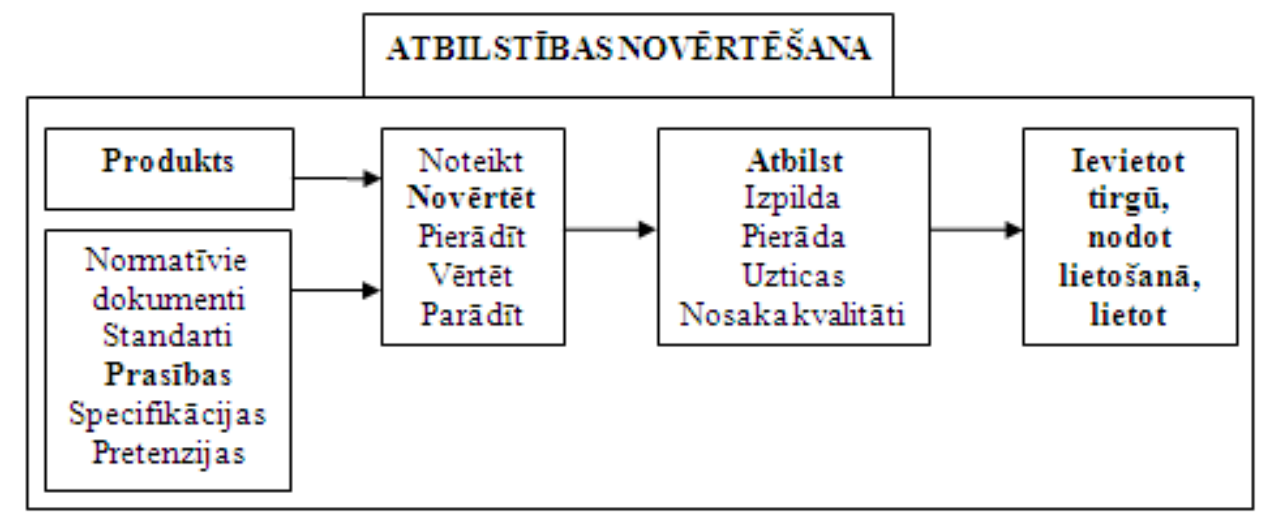

2.att. Ar jēdzienu 'atbilstības novērtēšana' saistīto terminu kopsakarības shēma.

No 2.attēlā parādītās kopsakarības shēmas autori secina, ka atbilstības novērtēšana būtībā ir darbība, process, procedūra, kurā tiek izvērtēts (salīdzināts) produkts un tā prasības. Tas tiek veikts, pielietojot atbilstības novērtēšanas procedūras.
Rezultātā tiek pieñemts lēmums par produkta atbilstību vai neatbilstību. Ja atbilstības novērtēšana tiek veikta reglamentētajā sfērā, pamatojoties uz pozitīvu atbilstības 
novērtēšanas vērtējumu, produktiem tiek piestiprināts marķējums pirms ievietošanas tirgū un nodošanas lietošanā.

Prasības ir viens no galvenajiem priekšnosacījumiem atbilstības novērtēšanai. Ja nav skaidri noteiktas prasības, nav iespējams novērtēt, vai objekts (saražotais produkts) tām atbilst. Prasības var noteikt dažādi, ar atšķirīgu detalizācijas pakāpi. ES līmen̄̄ prasības tiek noteiktas tiem produktiem, kas var ietekmēt cilvēka veselību, dz̄ivību un vidi.

Nozīmīga atbilstības novērtēšanas sastāvdaļa ir procedūras. To apliecina arī citu autoru viedokḷi. P.Druķis grāmatā ,Jaunā un globālā pieeja” norādījis, ka „Atbilstības novērtēšana ir sadalīta moduḷos, kas ietver noteiktu skaitu dažādu procedūru, kas pielietojamas plašam klientu lokam [8]". G.Stravbridžs (G.Strawbridge) norādījis, ka „Atbilstības novērtēšana ir darbība, kas uzskatāmi pierāda, ka specifiskās prasības, kas attiecas uz produktu, procesu, sistēmu, personu vai institūciju, ir izpildītas. Tā sevī ietver tādas darbības kā kalibrēšana, testēšana, inspicēšana un sertifikācija, kā arī atbilstības novērtēšanas institūciju akreditāciju." [9] Lai skaidrotu atbilstības novērtēšanas procesu un tajā ietvertās darbības jēdziena 'atbilstības novērtēšana', definīcijā jāiekḷauj norāde uz veidu, kā tā tiek veikta, t.i., uz atbilstības novērtēšanas procedūru, un nepieciešams definēt, kas ir 'atbilstības novērtēšanas procedūra'.

Kā trūkums pētījumā izvērtētajās definīcijās konstatēts, ka tajās nav norādes uz procesa galarezultātu jeb darbībām, kas tiek veiktas pēc atbilstības novērtēšanas. Atbilstības novērtēšanas rezultāts, ja konstatēta produkta atbilstība prasībām, ir apliecinājums par atbilstību (piemēram, sertifikāts) un/vai atbilstību apliecinošs marķējums. Ja konstatēts, ka produkts ir neatbilstošs, tiek izsniegts šo faktu apliecinošs dokuments. Uz atbilstības apliecinājuma esamību un nepieciešamību atbilstoši Jaunās pieejas un Globālās pieejas prasībām norādījis arī P.Druķis [8]. Nepieciešamība pēc atbilstības apliecinājuma izriet arī no ES normatīvajiem aktiem. [6]

Ievērojot identificētās nepilnības esošajās definīcijās, autori ierosina šādi pilnveidot termina 'atbilstības novērtēšana' definīciju: „Atbilstības novērtēšana ir process, kurā ar atbilstības novērtēšanas procedūrām tiek novērtēta objekta (produkta, procesa u.c.) atbilstība tam noteiktajām prasībām." „Kvalitātes terminu vārdnīcā” teikts, ka „Atbilstības novērtēšana ir jebkura darbība, kuras mērķis ir tieši vai netieši noteikt, vai izvirzītās prasības ir izpildītas". [10] Autori nepiekrīt šajā defin̄īijā ietvertajai norādei uz to, ka atbilstības novērtēšana var būt jebkura darbība. Lai objektīvi novērtētu, vai produkts atbilst tam noteiktajām prasībām, atbilstības novērtēšana jāveic atbilstoši noteiktajai kārtībai (atbilstības novērtēšanas procedūrai).

Ievērojot to, ka jēdzienu 'atbilstības novērtēšanas procedūra' plaši lieto atbilstības novērtēšanas jomā, bet nav dots tā definējums, autori ierosina šādu definīciju: „Atbilstības novērtēšanas procedūra ir darbība, kuras ietvaros tiek novērtēta objekta (produkta, procesa u.c.) atbilstība noteiktajām prasībām un pieņemts lēmums par apliecinājuma izsniegšanu un/vai marķējuma piestiprināšanu."

\section{ATBILSTĪBAS NOVĒRTĒŠANAS PROCEDŪRAS}

Atbilstoši Vecajai pieejai un Jaunajai pieejai atbilstības novērtēšanas apliecināšana produktiem atšķiras. Vecās pieejas gadījumā noteiktas konkrētas piemērojamās atbilstības novērtēšanas procedūras (piemēram, sertificēšana, inspicēšana). Jaunās pieejas gadījumā ražotājs pats var izvēlēties, kuru no piemērojamajām atbilstības novērtēšanas procedūrām - moduḷiem vai moduḷu kombinācijām - pielietot.

\section{a. Atbilstības novērtēšanas procedūras atbilstoši Vecajai pieejai}

\section{Jēdziens 'inspicēšana'}

Produktu inspicēšanu sāka veikt, lai nodrošinātu produkcijas kontroli ražošanas procesā un novērstu neatbilstošu produktu ievietošanu tirgū un nodošanu lietošanā. Tādējādi var uzskatīt, ka tieši ar inspicēšanu aizsākusies atbilstības novērtēšana.

Pamatojoties uz jēdziena 'inspicēšana' izvērtējumu, autori attēlojuši ar to saistīto terminu kopsakarības shēmu (skat. 3.attēlu).

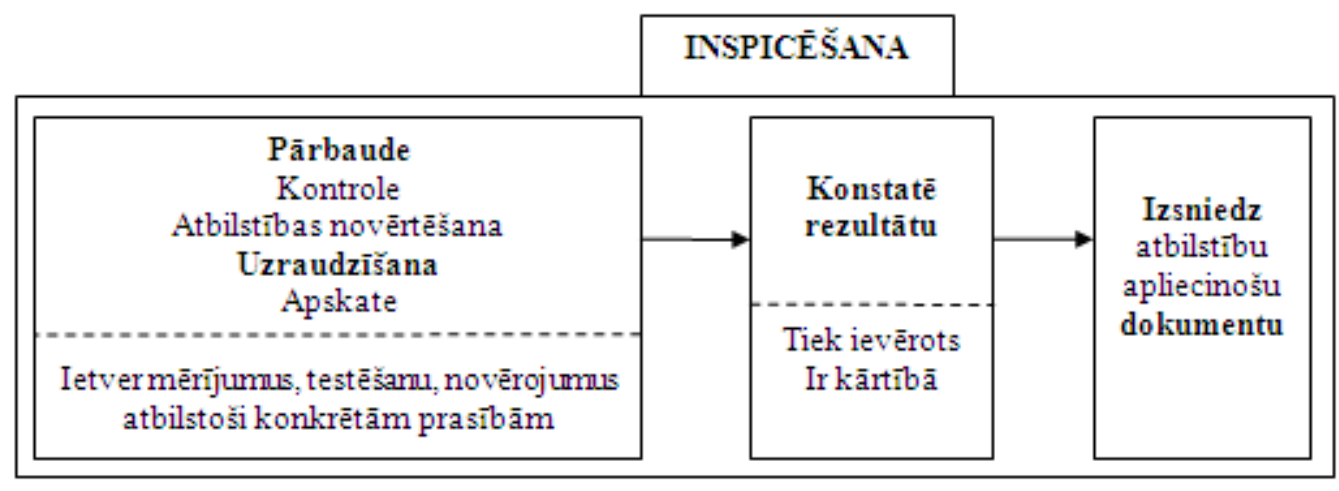

3.att. Ar jēdzienu 'inspicēšana’ saistīto terminu kopsakarības shēma.

Pēc būtības inspicēšanas procedūra ir kontrole, kuras laikā tiek konstatēts, vai faktiskā situācija atbilst plānotajai. Tādējādi inspicēšanu var uzskatīt par fakta konstatāciju, kuras galarezultātā apstiprinās vai neapstiprinās objekta faktiskā atbilstība noteiktajām prasībām. Līdz ar to inspicēšanu var uzskatīt par novērtēšanas/uzraudzības procedūru.

Inspicēšanas rezultāta pieņemšanai un tā ticamības nodrošināšanai reizēm tiek izmantotas atbalsta procedūras 
$2013 / 24$

(piemēram, testēšana) un palīgdarbības (piemēram, audits). To apliecina arī iepriekš minētā „Kvalitātes terminu vārdn̄̄cā” ietvertā definīcija [10].

Autori secina, ka jēdziena 'inspicēšana' definējumi ir ļoti vispārīgi un sevī neietver visus inspicēšanas procesa posmus. Piemēram, Biznesa leksikas skaidrojošajā vārdnīcā noteiktā definīcija „Inspicēšana - pārbaude, kontrole, inspekcija” [11] loti vispārīgi raksturo veicamo darbību mērķi. „Kvalitātes terminu vārdn̄̄cā” ietverta šāda definīcija: „Inspicēšana atbilstības novērtēšana, izmantojot novērojumus un spriedumus, papildinot tos ar piemērotiem mērījumiem, testēšanu vai novērtēšanu." [10] Šajā definīcijā ir ietverts skaidrojums, kuras metodes var izmantot atbilstības novērtēšanā, bet nav norādīts - precīzi kādā veidā tiek veiktas inspicēšanas darbības. Macmillan English dictionary for advanced learners ietvertā definīcija raksturo veicamās darbības un ir nepiln̄̄ga attiecībā uz pielietotajām metodēm un atbalsta jeb palīgprocedūrām inspicēšanas rezultāta ticamības nodrošināšanai - „Inspicēšana: 1. oficiāls process, lai pārbaudītu, ka lietas ir atbilstošā stāvoklī, vai ka cilvēki dara to, kas tiem būtu jādara; 2. darbība, kuras ietvaros kaut ko veic uzman̄̄gi, nolūkā kontrolēt, vai to veic apmierinoši." [4]

Par atbilstošāko definīciju, kas salīdzinoši vispusīgāk raksturo jēdzienu 'inspicēšana', autori uzskata likumā ,Par atbilstības novērtēšanu” noteikto: „Inspicēšana - produkta projektēšanas stadiju, produkta, procesa vai pakalpojuma pārbaude un tā atbilstības noteikšana konkrēti izvirzītām vai vispārīgām prasībām, pamatojoties uz profesionālu spriedumu". [4] Definīcija aptver gan inspicēšanas veikšanas veidu, gan norāda uz to, ka, pieņemot galīgo lēmumu, nepieciešams ievērot arī veiktās atbalsta procedūras un palīgdarbības, kas nodrošina pamatotu lēmumu pieṇemšanu.

\section{Jēdziens 'sertificēšana'}

Daļa sabiedrības uzskata, ka atbilstības novērtēšana ir sertificēšana. Šāds uzskats veidojies vēsturiski, jo atbilstības novērtēšanas sistēmas izveides sākumposmā daudzās valstīs, tostarp arī Latvijā, kā obligāta tika noteikta visu reglamentētai jomai pakḷauto produktu sertificēšana. To apstiprina arī
M.Rurānes grāmatā „Ražošana” minētais: „Parasti valstīs, kurās notiek pāreja uz ekonomiku, kas balstīta uz tirgus attiecībām, pārejas periodā tiek ieviesta sertifikācija. Tā tiek izmantota līdz konkrētu normu pieņemšanai, lai apliecinātu kvalitātes atbilstību." [13]

Longman Dictionary of Contemporary English noteiktā definīcija „Sertificēšana ir process, kura ietvaros kādam vai kaut kam tiek izsniegts oficiāls dokuments, kas apliecina, ka tam ir atļauts veikt konkrētu darbu, ka kaut kas ir labas kvalitātes u.c. [5]" norāda uz atbilstības apliecinājuma izsniegtā sertifikāta - nozīmīgumu.

„Biznesa leksikas skaidrojošā vārdnīcā” ietvertā definīcija „Sertificēšana - atestēšana, atestācija - shēma, pēc kuras tiek izsniegti dokumenti, kas apliecina kādas personas, tehniskas ierīces vai rūpnieciska procesa atbilstību standartiem," [11] norāda uz to, ka sertificēšana ir secīgs darbību kopums, kas orientēts uz noteikta objekta atbilstības apliecināšanu.

Lai nodrošinātu sertificēšanas ietvaros veiktā atbilstības izvērtējuma objektivitāti, būtiski, lai novērtējumu veiktu neatkarīga trešā puse, kā tas norādīts A.Klausa grāmatā „Zinības vadītājam”: „Sertificēšana - no ražotāja un patērētāja neatkarīgas trešās puses darbība, ar noteiktu ticamību apliecinot, ka attiecīgais produkts, process vai pakalpojums atbilst noteiktam standartam vai citam normatīvajam dokumentam." [14]

Dažos no autoru apgalvojumiem, tostarp arī M.Rurānes grāmatā „Uzṇēmējdarbības organizācija un plānošana” ietvertajā apgalvojumā ,Sertificēšana apliecina, ka produkcija ir izmēǵināta vai pārbaudīta pietiekami kvalitatīvi," [15] norādīta nepārprotama sertificēšanas un kvalitātes saistība nosakot, ka sertificētie produkti ir kvalitatīvi. Autori vēlas uzsvērt, ka sertificēšana apliecina objekta atbilstību tam izvirzītajām prasībām. Produktu par kvalitatīvu var uzskatīt vien̄̄gi gadījumā, ja noteikts, ka ar produkta kvalitāti tiek saprasta tā atbilstība tam noteiktajām prasībām.

Izvērtējot jēdziena 'sertificēšana' dažādās definīcijas, autori izveidoja ar to saistīto terminu kopsakarības shēmu (skat. 4.attēlu).

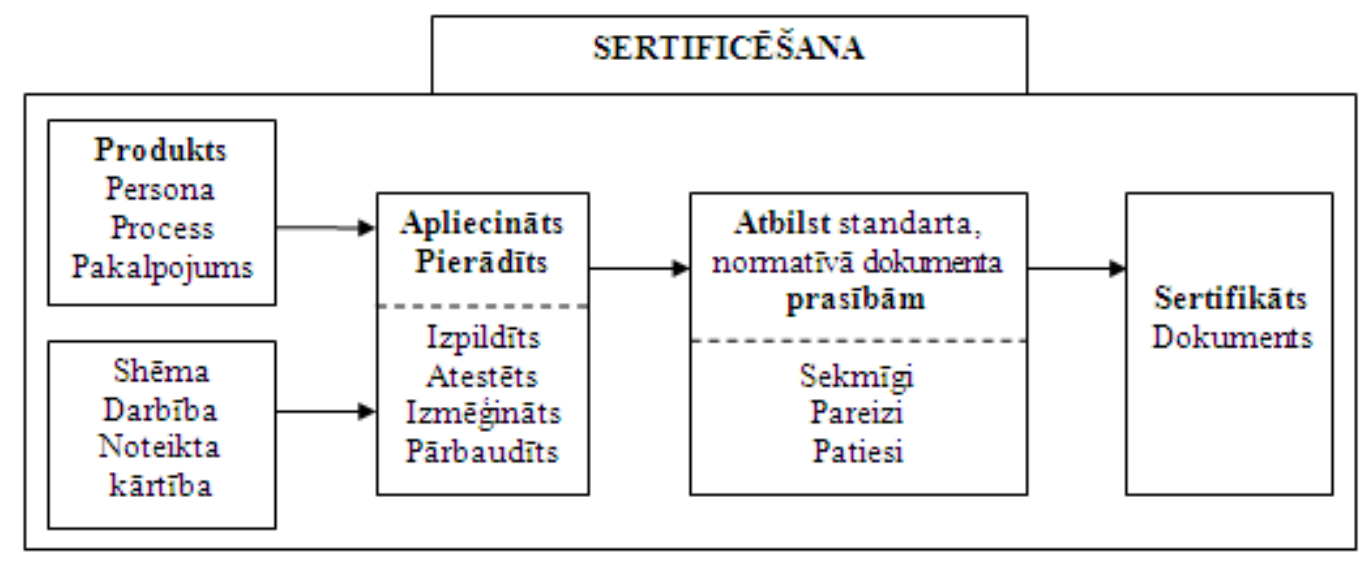

4.att. Ar jēdzienu 'sertificēšana' saistīto terminu kopsakarības shēma.

No 4.attēlā parādītās kopsakarības shēmas autori secina, ka sertificēšana ir plaši pielietota atbilstības novērtēšanas procedūra un tās objekts var būt gan produkts, gan persona, gan process, gan pakalpojums u.c. Tas ir process, kurā 
neatkarīga trešā puse pārbauda, vai produkts izpilda tam noteiktās prasības, vai personai ir nepieciešamā kompetence veikt konkrētas darbības, vai izveidota kvalitātes vadības sistēma uzņēmumā u.c. Par apliecinājumu atbilstībai tiek izsniegts sertifikāts.

Autori uzskata, ka sertificēšanas procesu visatbilstošāk raksturo likumā „Par atbilstības novērtēšanu” noteiktā definīcija: „Sertificēšana — neatkarīgas trešās personas darbība, apliecinot, ka attiecīgais produkts, process, pakalpojums vai persona atbilst normatīvajā aktā vai standartā noteiktajām prasībām," [12] jo tā raksturo galvenās procesa iezīmes: objektu, iesaistītās puses un procesa mērķi.

Salīdzinot dažādās definīcijas, secināts, ka Latvijas autori (A.Klauss un M.Rurāne) saviem termina 'sertifikācija' skaidrojumiem par pamatu izmantojuši šo definīciju. Autori uzskata, ka pārējās izvērtētās jēdziena 'sertificēšana' definīcijas pilnībā neraksturo visu sertificēšanas procesu, jo tajās kā galvenā tiek akcentēta sertifikāta izsniegšanu, nevis sertificēšanas process un tā mērķis.

\section{Jēdziens 'kalibrēšana'}

Izvērtējot jēdziena 'kalibrēšana' definīcijas, autori secina, ka kalibrēšanas darbības iedalāmas divos veidos:

1) process, lai novērtētu konkrētā mērīšanas līdzekḷa vai etalona precizitāti $[10,12,16,17]$;

2) process, lai ieregulētu ierīci tā, lai tā noteiktos apstākḷos darbotos atbilstoši prasībām $[4,5]$.

Jēdzienu 'kalibrēšana' galvenokārt pielieto metroloğijas jomā, lai nodrošinātu veikto mērījumu ticamību, noteiktos apstākḷlos reproducējot konkrēto mērvienības etalonu. Otrā veida defin̄icija raksturo ierīces pārbaudi pirms tās pielietošanas, nepieciešamības gadījumā ierīces uzstādījumos veicot noteiktas korekcijas, kas pilnībā neatbilst ar jēdzienu 'atbilstības novērtēšana' apzīmēto darbību kopumam.

Autori identificējuši ar jēdzienu 'kalibrēšana' saistītos terminus un attēlojuši to kopsakarības shēmu (skat. 5.attēlu).

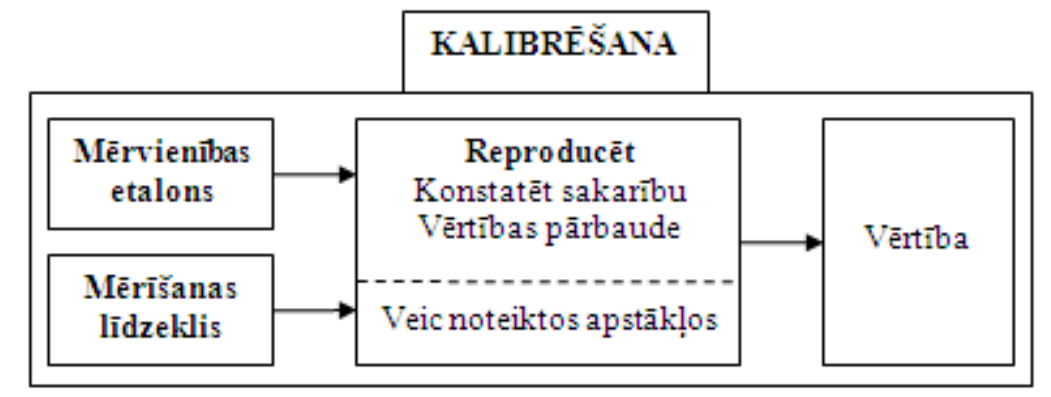

5.att. Ar jēdzienu 'kalibrēšana' saistīto terminu kopsakarības shēma.

Kopsakarības shēma apstiprina, ka atbilstības novērtēšanā tiek pielietota pirmā veida definīcija, kas orientēta uz mērījumu vienotības nodrošināšanu, lai atbilstības novērtēšanas darbību rezultāti būtu ticami un precīzi.

Autori uzskata, ka visatbilstošāk faktiskajam izpildījumam kalibrēšanas procedūru raksturo normatīvajos aktos ietvertās termina 'kalibrēšana' definīcijas. Tās salīizinot konstatēts, ka likumā „Par atbilstības novērtēšanu” ietverts precīzāks kalibrēšanas darbības definējums: „Kalibrēšana - operācija, kuras gaitā noteiktos apstāklı kos konstatē sakarību starp mērīšanas līdzekḷu vai mērī̌šanas sistēmas uzrādīto lielumu vērtībām, materiālā mēra vai references materiāla vērtībām un no atbilstošā mērvienības etalona reproducētām vērtībām." [12] Lai nodrošinātu vienotu izpratni, identiski šādu termina 'kalibrēšana' definējumu būtu nepieciešams ietvert arī citos Latvijas Republikas normatîvajos aktos.

\section{Jēdziens 'testēšana'}

Līdzīgi kā par jēdzienu 'kalibrēšana', arī par jēdzienu 'testēšana' ir dažāda izpratne.

Ar jēdzienu 'testēšana' saistīto terminu kopsakarības shēmu skatīit 6.attēelā.

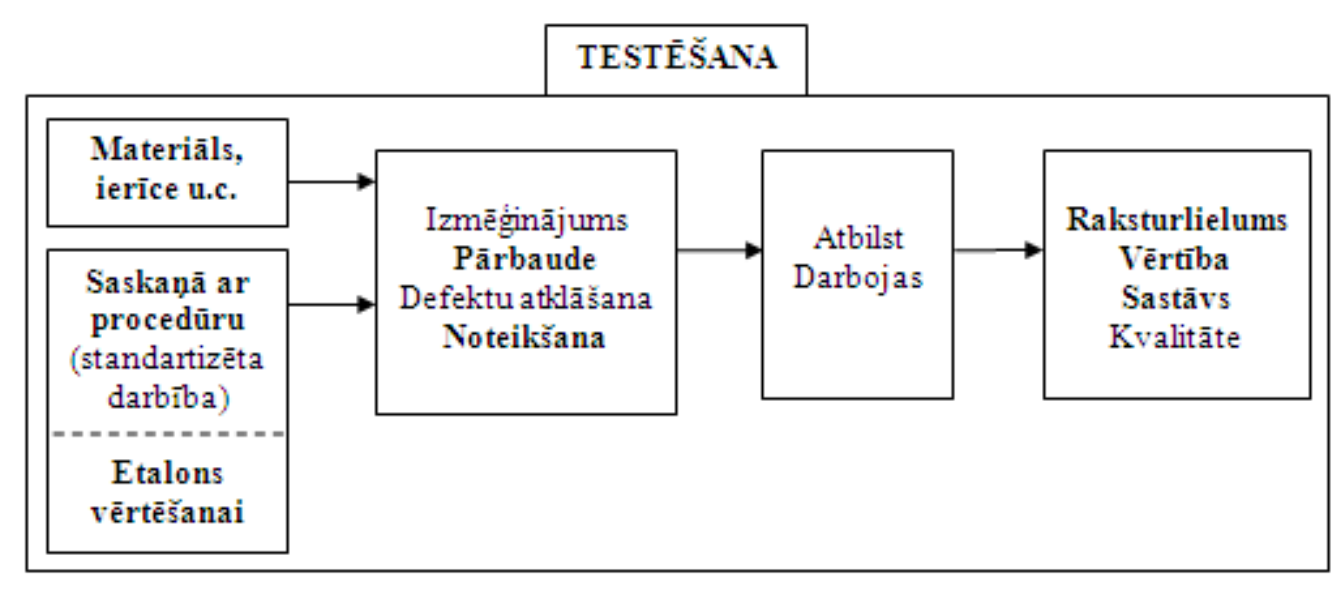

6.att. Ar jēdzienu 'testēšana' saistīto terminu kopsakarības shēma. 
$2013 / 24$

Sabiedrības izpratnē jēdziens 'testēšana' galvenokārt saistās ar izmēǵinājumu veikšanu produkta projektēšanas stadijā vai konkrētas ierīces darbības spējas pārbaudi. [4] Šajā rakstā izvērtēts cita jēdziena 'testēšana' izpratne - process, kurā tiek iegūts konkrēta objekta rezultāts, izteikts noteiktās vērtībās.

No kopsakarības shēmas (6.attēlā) redzams, ka galvenais priekšnoteikums testēšanas veikšanai ir standartizēta procedūra. Atbilstoši tai tiek veiktas testēšanas darbības, tādējādi nodrošinot testēšanas rezultātu objektivitāti un salīdzināmību. Testēšanas ietvaros tiek veikta konkrēta objekta pārbaude un identificēti konkrēti raksturlielumi (vērtības), kas raksturo objekta faktisko stāvokli un sastāvu.

Autori uzskata, ka visprecīzāk šai kopsakarības shēmai atbilst definējums, kas noteikts likumā „Par atbilstības novērtēšanu”: „Testēšana - atbilstības novērtēšanas objekta viena vai vairāku raksturlielumu noteikšana saskaņā ar procedūru." [4] Salīdzinot ar citām definīcijām, šajā definīcijā veicamās testēšanas darbības nav konkrēti minētas, līdz ar to netiek ierobežots testēšanas veids. Turklāt tajā minēta arī norāde uz testēšanas procedūru, kas ir būtisks priekšnoteikums testēšanas veikšanai, kā arī skaidrots, ka vienas testēšanas ietvaros vienlaicīgi iespējams noteikt vienu vai vairākus raksturlielumus.

Sertificēšanā un inspicēšanā tiek vērtēta objekta (produkta, personas, procesa u.c.) atbilstība prasībām. Sertificēšanā tiek veikta objekta detalizēta izvērtēšana atbilstoši prasībām vai projektam, ko var uzskatīt par nodrošināšanas procedūru. Savukārt inspicēšanā tiek konstatēta atbilstība vai neatbilstība izvirzītajām prasībām un to var uzskatīt par novērtēšanas/uzraudzības procedūru. Sertificēšana un inspicēšana ir procedūras, kas pilnībā atbilst ar jēdzienu 'atbilstības novērtēšana' definētajam darbību kopumam.

Testēšanas un kalibrēšanas rezultātā tiek iegūts konkrēts raksturlielums (vērtība), ko var izmantot sertificēšanā vai inspicēšanā. Testēšanas un kalibrēšanas rezultātā netiek pieņemts lēmums par produkta atbilstību tam izvirzītajām prasībām. Lìdz ar to testēšana un kalibrēšana nav uzskatāmas par atbilstības novērtēšanas procedūrām. Tās ir atbilstības novērtēšanas atbalsta procedūras jeb palīgprocedūras (skat. 7.attēlu).

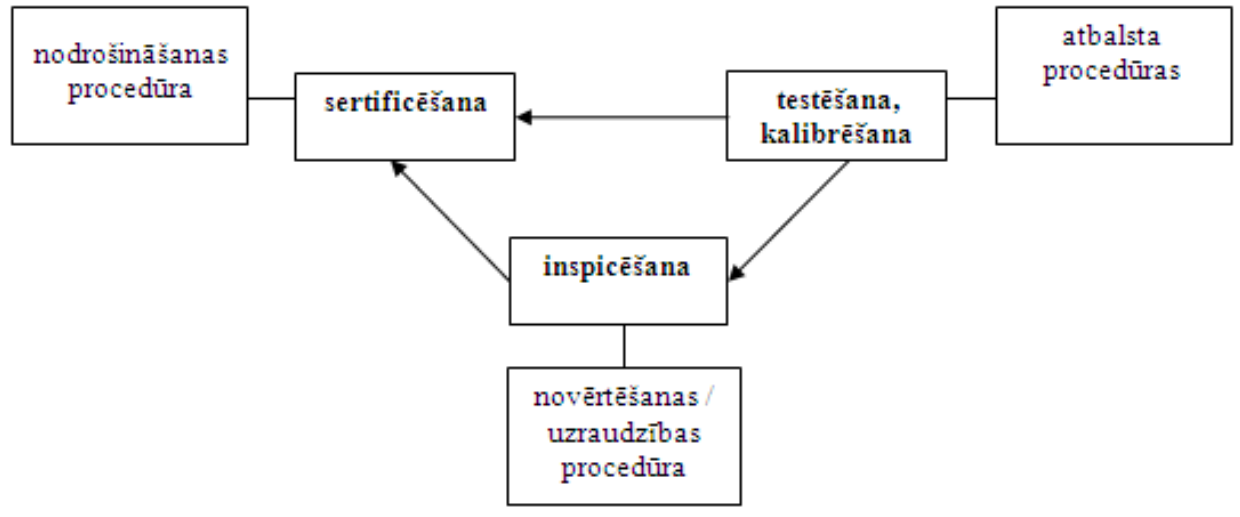

7.att. Vecās pieejas atbilstības novērtēšanas procedūru savstarpējā kopsakarības shēma.

Izvērtējot Vecās pieejas atbilstības novērtēšanas procedūru jēdzienu definīcijas, autori secina, ka tās ir atbilstošas faktiski veicamajām darbībām, un tādēḷ nav nepieciešams tās pilnveidot.

\section{b. Atbilstības novērtēšanas procedūras atbilstoši Jaunajai pieejai}

Jaunajā pieejā atbilstības novērtēšanas procedūras sauc par moduliem. Visas atbilstības novērtēšanas darbības tiek iedalītas astonos pamatmoduḷos. Lielākajai dal̦ai no tiem noteikti apakšmoduli [6], tādējādi specificējot konkrēto atbilstības novērtēšanas procedūru.

Jaunās pieejas atbilstības novērtēšanas procedūru - moduḷu skaidrojums [6, autori]:

A modulis - iekšējā produkcijas kontrole (internal production control) - attiecas uz iekšējo projektēšanas un ražošanas kontroli. Atbilstības novērtēšanas institūcijas dalība nav nepieciešama, izņemot gadījumus, kad nepieciešama specifisku testu veikšana un ražotnes laboratorijai nav attiecīgas kompetences veikt šādus testus.

B modulis - EK tipa novērtēšana (EC type examination) attiecas uz projektēšanas procesu. Lai nodrošinātu produkta atbilstību, papildus ražošanas stadijā jāveic viens no šādiem moduḷiem (C, D, E vai F). Š $\overline{1}$ modul̦a veikšanai tiek piesaistītas atbilstības novērtēšanas institūcijas.

$\mathrm{C}$ modulis - tipa novērtēšana (conformity of type) - attiecas uz ražošanas procesu un nodrošina pierādījumus tipa novērtēšanai.

D modulis - ražošanas kvalitātes nodrošināšana (production quality assurance) - attiecas uz ražošanas procesu. Atbilstības novērtēšanas institūcija jāpiesaista ražotāja atbilstības sertifikācijas veikšanai, kas var ietver ražošanu, gala pārbaudi vai produktu testēšanu.

E modulis - produkta kvalitātes nodrošināšana (product quality assurance) - attiecas uz ražošanas procesu. Atbilstības novērtēšanas institūcija jāpiesaista ražotāja atbilstības sertifikācijas veikšanai, kas sevī ietver beigu pārbaudi un produktu testēšanu.

F modulis - produkta verifikācija (product verification) attiecas uz ražošanas procesu. Nodrošina tipa novērtēšanas apliecināšanu. Atbilstības novērtēšanas procedūru veikšanai nepieciešams piesaistīt atbilstības novērtēšanas institūciju.

$\mathrm{G}$ modulis - vienības verificēšana (unit verification) attiecas gan uz projektēšanu, gan ražošanas procesa kontroli. Atbilstības novērtēšanas institūcijai jāveic katra produkta 
testēšana, pamatojoties uz to, var tikt izsniegts atbilstības sertifikāts.

H modulis - pilna kvalitātes nodrošināšana (full quality assurance) - attiecas gan uz projektēšanu, gan ražošanas procesa kontroli. Atbilstības novērtēšanas institūcija jāpiesaista ražotāja kvalitātes sistēmas sertifikācijas veikšanai, kas sevī ietver projektēšanas, ražošanas, gala pārbaudi un produktu testēšanu.

Ar Jaunās pieejas atbilstības novērtēšanas procedūru modulu savstarpējo saikni un savstarpējo sakarību autori piedāvā iepazīties 8.attēlā.

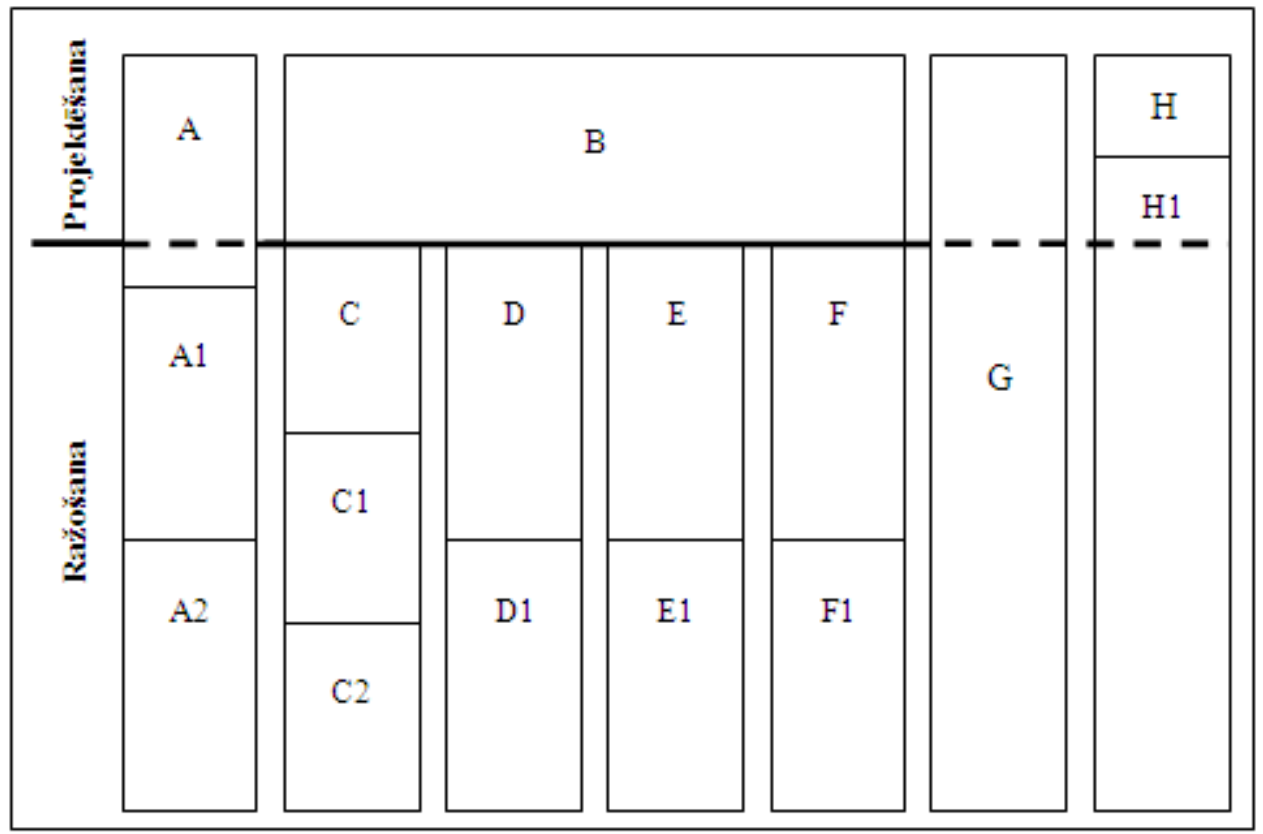

8.att. Jaunās pieejas atbilstības novērtēšanas procedūru - moduḷu saikne un savstarpējā sakarība [6].

Atbilstības novērtēšanas moduḷi tiek iedalīti pēc dažādiem kritērijiem: kādā posmā - projektēšanas un/vai ražošanas atbilstības novērtēšana tiek veikta; kas veic atbilstības novērtēšanas darbības; kāda veida darbības tiek veiktas, lai nodrošinātu produktu atbilstību: iekšējā kontrole, verificēšana vai ieviesta kvalitātes vadības sistēma.

Atbilstoši Jaunajai pieejai ražotājs var izvēlēties, kādā veidā apliecināt produkta atbilstību (kuru no atbilstības novērtēšanas moduliem izmantot). Tas vienlaikus gan atvieglo ražotāja darbību, jo ražotājs pats var izvēlēties piemērotāko moduli, gan sarežǵī - jo tam jābūt pietiekamām zināšanām par atbilstības novērtēšanas jomu, lai spētu izvērtēt, kurš no moduḷiem ir atbilstošāks konkrētu produktu ražošanai.

Izvērtējot ar Jaunās pieejas atbilstības novērtēšanas procedūrām - moduḷiem saistīto informāciju, autori secina, ka nav nepieciešams izstrādāt katram konkrētam modulim noteiktu defin̄iciju, jo katrā modulī ietvertas atšķirīgas specifiskas atbilstības novērtēšanas darbības. Lai to izprastu visas moduḷa nodrošināšanā iesaistītās puses, nepieciešams paplašināts darbību skaidrojums. Lakoniska izteiksme definīcijas veidā nebūtu piel̦aujama.

\section{IV.ATBILSTĪBAS NOVĒRTĒŠANAS ELEMENTI}

Atbilstības novērtēšana ir cieši saistīta ar tādiem elementiem kā akreditācija, standartizācija un metroloǵija. Lai nodrošinātu atbilstības novērtēšanas veicēju kompetenci, tiek veikta atbilstības novērtēšanas institūciju akreditācija. Lai novērtētu produktu atbilstību prasībām, nepieciešams, lai tiem sākotnēji būtu noteiktas būtiskās un tehniskās prasības, kas bieži vien tiek ietvertas standartos. Savukārt, lai nodrošinātu rezultātu ticamību, nepieciešams nodrošināt mērījumu izsekojamību. Ar atbilstības novērtēšanas elementiem autori piedāvā iepazīties 9.attēlā.

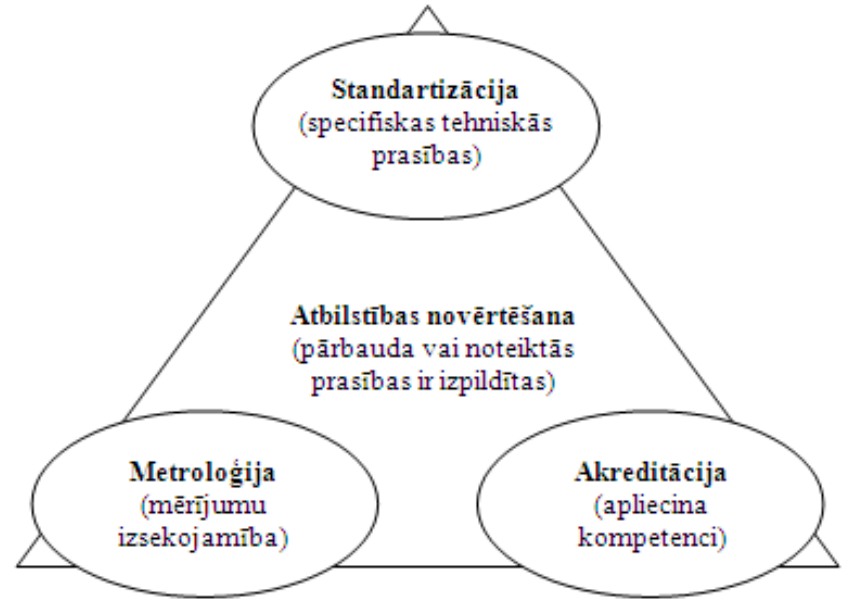

9.att. Atbilstības novērtēšanas elementi [18].

Autori uzskata, ka mūsdienās viens no sekmīgas uzṇēmējdarbības priekšnosacījumiem globālajā tirgū ir spēja apzināties atbilstības novērtēšanas elementu nozīmīgumu un izmantot to sniegtās iespējas (piemēram, iesaistīties standartu izstrādē, produktu ražošanā ievērot starptautisko standartu prasības, izvēlēties izdevīgāko no atbilstības novērtēšanas 
$2013 / 24$

moduḷiem, piesaistīt paziņotās institūcijas atbilstības novērtēšanas darbību veikšanai u.c.).

a. Akreditācija

Vārds 'akreditācija' cēlies no franču valodas vārda 'accrediter', kas sākotnēji nozīmēja sūtṇa vai vēstnieka iecelšanu amatā. Šodien jēdziens 'akreditācija' tiek lietots daudz plašāk, un tas attiecas uz fiziskas vai juridiskas personas pilnvarošanu, tiesību piešķiršanu tai vai to veikto darbību kvalitātes garantēšanu. [19]

Jēdzienu 'akreditācija' raksturo dažādas definīcijas. Piemēram, „Ilustrētajā svešvārdu vārdnīcā” norādīts, ka „Akreditācija ir oficiāla laboratorijas, sertificēšanas vai inspicēšanas institūcijas atzī̌sana, nosakot tās kompetenci konkrētu uzdevumu veikšanai". [20] Tādējādi akcentējot objektu, kas tiek akreditēts, un piel̦aujot iespēju, ka var tikt akreditētas dažādas atbilstības novērtēšanas institūcijas. Uz akreditācijas kā veikto darbību ticamības katalizatoru norādījis A.Zuckermans: „Akreditācija ir domāta, lai piešksirtu ticamību sertificēšanas vai testēšanas praksei." [21]

Vispusīgāk jēdziens 'akreditācija' noteikts standartā LVS EN ISO/IEC 17000: 2005 „Atbilstības novērtēšana -Vārdnīca un vispārīgie principi", nedaudz plašāk aprakstot arī pašu atzī̌sanas procedūru: ,Akreditācija ir trešās puses atz̄̄̌sana, kas saistīta ar atbilstības novērtēšanas institūciju formālo paziņošanu, lai parādītu tās kompetenci veikt specifiskus atbilstības novērtēšanas uzdevumus." [7]

Izvērtējot dažādos literatūras avotos ietvertās jēdziena 'akreditācija' definīcijas, autori attēloja ar šo jēdzienu saistīto terminu kopsakarības shēmu (skat. 10.attēlu).

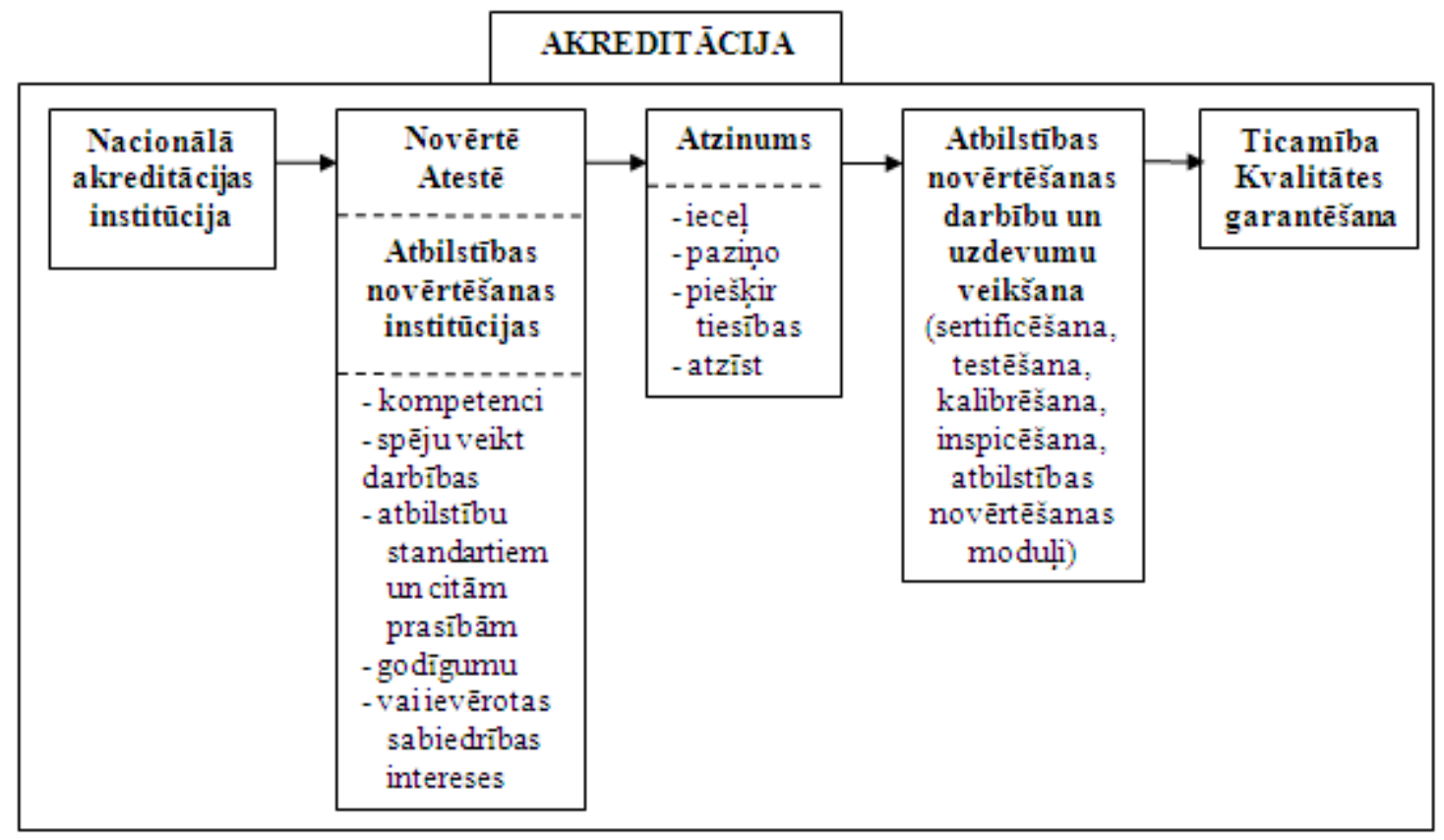

10.att. Ar jēdzienu 'akreditācija' saistīto terminu kopsakarības shēma.

No kopsakarības shēmas secināts, ka atbilstības novērtēšanas jomā akreditācija ir process, kurā novērtē institūcijas kompetenci, spēju veikt konkrētas darbības, ievērot prasības, demonstrēt godīgumu, personāla zināšanas un prasmes. Pozitīva novērtējuma rezultātā tiek izsniegts atzinums - akreditācijas apliecība. Ar tā izsniegšanas brīdi atbilstības novērtēšanas institūcijai tiek pieškiirtas tiesības veikt konkrētas atbilstības novērtēšanas procedūras noteiktā jomā. Akreditācijas procesā veiktais atbilstības novērtēšanas institūcijas kompetences novērtējums ir pamats produktu kvalitātes nodrošināšanai (garantēšanai) un institūcijas veikto atbilstības novērtēšanas rezultātu ticamībai. Tas vienlaikus ir priekšnoteikums savstarpējai atzī̌̌anai.

Lai nodrošinātu vienlīdzīgu akreditācijas principu ievērošanu visā ES, 2008.gadā pieņemta regula Nr.765/2008 [22] par akreditāciju un tirgus uzraudzību, kas nosaka galvenos principus akreditācijas sistēmas organizācijai ES dalībvalstīs nacionālā līmen̄̄. Regulā ietverta termina 'akreditācija' definīcija, kas līdzīgā redakcijā pārṇemta likumā „Par atbilstības novērtēšanu”: „Akreditācija - nacionālās akreditācijas institūcijas veikta atestācija par atbilstības novērtēšanas institūcijas kompetenci un spēju veikt specifiskas atbilstības novērtēšanas darbības." [12] Līdz ar vienotas likumdošanas un terminoloǵijas pieņemšanu ES, tiek pilnveidota izpratne par akreditācijas procesu un veicināta vienotas terminoloǵijas pielietošana. Īstenojot vispusīgu un objektīvu akreditāciju, iespējams nodrošināt savstarpējo atzī̌sanu gan atbilstības novērtēšanas institūcijām, to veiktajām darbībām, pieņemtajiem lēmumiem un izsniegtajiem rezultātiem, gan dažādās dalībvalstīs ražotajiem produktiem.

Latvijā akreditācija ir priekšnoteikums atbilstības novērtēšanas institūciju darbībai reglamentētajā jomā, kā ar̄̄ nereti kompetences apliecināšanai akreditācija tiek izmantota arī nereglamentētajā jomā.

Atbilstības novērtēšanas procedūras dalībvalstīs nacionālā līmenī veic atzītas atbilstîbas novērtēšanas institūcijas. 
Priekšnoteikums to darbībai ir atbilstība prasībām un/vai kompetences apliecināšana akreditējoties, kas ne visās dalībvalstīs un ne visās jomās ir obligāts kritērijs. Ja atbilstības novērtēšanas institūcija vēlas sniegt savus pakalpojumus reglamentētajā sfērā citās ES dalībvalstīs, tai jāiegūst paziñotās institūcijas statuss.

Vienlaikus autori vēlas norādīt uz š̄ termina neviennozīmīgo tulkojumu latviešu valodā. Angḷu valodas termins 'notified body' latviešu valodā tiek tulkots gan kā 'notificētā institūcija', gan kā 'paziņotā institūcija'.

Lai izvērtētu termina latviskojumu atbilstoši tajā ietverto darbību kopumam, autori izvērtēja jēdzienu 'paziņotā institūcija' un ar to saistīto terminu ('notifikācija', 'notificēt', 'paziņot') definīcijas. Terminam 'notify' ir vairāki tulkojumi: paziṇot, notificēt, informēt un darīt zināmu. Vārds 'notificēt' veidojies no franču valodas vārda 'notification', kas savukārt cēlies no latīnu valodas vārda 'notificare' un nozīmē 'darīt zināmu'. Ar jēdzienu 'notificēt' apzīmē darbību, kad tiek nosūtīts kādas valsts oficiāls rakstisks paziņojums citai valstij par savu nostāju kādā jautājumā. Šāds termina skaidrojums pilnībā atbilst procedūrai, kas saistīta ar atbilstības novērtēšanas institūciju paziņošanu Eiropas Komisijai un citām dalībvalstīm, lai tās iegūtu paziņotās institūcija statusu. Līdz ar to paziņošanas procedūra (darbība) latviešu valodā atbilstoši būtu apzīmējama ar terminu 'notifikācija'.

Atbilstoši veiktajam izvērtējumam, autori uzskata, ka visatbilstošākais jēdziena 'notified body' tulkojums latviešu valodā ir 'paziņotā institūcija', jo galvenais notificēšanas darbības mērķis ir paziņot par konkrētās atbilstības novērtēšanas institūcijas kompetenci darboties konkrētā jomā ES.

N̦emot vērā, ka terminam 'pazinotā institūcija' nav noteiktas definīcijas, tikai informatīvas to apzīmējošas vārdkopas, autori ierosina sekojošu definīciju: „Paziņotā institūcija ir akreditēta atbilstības novērtěšanas institūcija, par kuras kompetenci darboties noteiktā jomā atbildīgā institūcija informējusi Eiropas Komisiju." Definīcijā autori skaidrojuši notifikācijas procesu, kā arī vienlaikus ietvēruši norādi, ka akreditācijai jābūt kā obligātam kritērijam paziņotajām institūcijām, jo vien̄̄gi akreditācijas procesā ir iespējams objektīvi un vispusīgi nodrošināt atbilstības novērtēšanas institūcijas novērtēšanu atbilstoši prasībām un nodrošināt tās atzī̌sanu starptautiskā līmenī.

\section{b. Standartizācija}

Standartizācija paredz vienotu noteikumu un normu piemērošanu visiem tirgus dalībniekiem, t.sk. ražotājiem. Ar standartizācijas palīdzību uzṇēmumos tiek noteikti un izmantoti vienoti noteikumi un normas, kuru uzdevums ir nodrošināt ekonomiju un ražošanas procesa darbību [13]. Standartizācijas process veicinājis arī savstarpējo atzī̌sanu valstu starpā, kas savukārt veicinājis starptautisko tirdzniecību.

Jēdzienu 'standartizācija' raksturo dažādas definīcijas. Piemēram, „Ilustrētajā svešvārdu vārdnīcā” teikts, ka „Standartizācija: 1. standartu izstrādāšana; 2. izejvielu, pusfabrikātu, gatavu ražojumu reglamentēšana (liela uzṇēmuma, visas valsts vai starptautiskā mērogā); 3. ražojumu vai citu objektu daudzveidības ierobežošana līdz vienam vai dažiem tipveida paraugiem." [20], tādējādi aprakstot dažādus standartizēšanas veidus un dažādus standartizācijas galarezultātus. Tas ietverts arī „Zinātnes un tehnologijas vārdnīcā” noteiktajā definīcijā: ,Standartizācija ir noteikumu, normu u.tml. izstrādāšana tādu uzdevumu risināšanai, kas attiecīgā nozarē atkārtojas." [16] M.Rostovska norādījusi, ka „Standartizācija ir preču un pakalpojumu kvalitātes kritēriju izstrādāšana un noteikšana," [23] kas raksturo standartizācijas un kvalitātes saistību, pie nosacījuma, ka ar kvalitāti tiek saprasta produkta atbilstība tam noteiktajām prasībām. Līdzīgu definīciju sniegusi arī M.Rurāne [13].

„Standartizācijas likumā” noteikta šāda definīcija: „Standartizācija ir darbību kopums, kuru mērķis ir noteikt vispārīgus un daudzkārt piemērojamus principus esošo vai perspektīvo uzdevumu risināšanai, lai tādējādi radītu nosacījumus optimālai sakārtotībai noteiktā jomā." [24] Autori uzskata, ka minētā definīcija nav pietiekami vispārīga un orientēta uz galveno mērķi - standartu izstrādi. Iegūtais rezultāts - optimāla sakārtotība noteiktā jomā ir neviennozīmīgs un grūti realizējams. Turklāt standartizācijas darbības veicamas secīgi un mērkstiecīgi, iesaistot visas ieinteresētās puses, jo tikai tādā veidā iespējams izstrādāt labāko risinājumu konkrētā jomā.

Par visatbilstošāko uzskatāma N.Kozlovska un A.Vinogradova piedāvātā defin̄icija: „Standartizācija ir noteikumu pieņemšana un lietošana, piedaloties visām ieinteresētajām pusēm, lai noregulētu noteiktas nozares darbību, kā arī lai sasniegtu kopēju optimālu ekonomiju, ievērojot ekspluatācijas noteikumus un drošības prasības." [25] Tajā ietverts visvairāk identificēto standartizācijas procesa elementu, tomēr definējums īsti neatbilst mūsdienu izpratnei par standartizācijas procesu. Līdz ar to autori identificējuši nepieciešamību pilnveidot esošo termina 'standartizācija' definīciju un piedāvā šādu: ,Standartizācija ir process, kurā iesaistītās puses nosaka prasības un kārtību, kas ir labākā iespēja, lai noregulētu noteiktas jomas darbību."

Standartizācija sevī ietver informāciju gan no pagātnes, gan no tagadnes, gan attiecināmu uz nākotni. Pamatojoties uz pieredzi pagātnē, tiek izdarīti secinājumi un identificēta nepieciešamība pilnveidoties. Tagadnē tiek konstatēta nepieciešamība pieņemt vienotas prasības vai pilnveidot esošās, un meklēti risinājumi, kā to sasniegt. Standartizācijas rezultāts galvenokārt orientēts uz nākotni, lai saražotais produkts būtu ilgtspējīgs, ražošanas procesā tiktu pielietotas modernas tehnologijas, konkrētā joma tiktu optimāli sakārtota un noregulēta nozares darbība, produkta kvalitāte un piemērotība lietošanai uzlabotos, tiktu sasniegta kopēja optimālā ekonomija. Tādēl būtiski standartizācijas procesā iesaistīt visas puses (gan valstiskās, gan nevalstiskās organizācijas, kā arī produkta ražotājus, patērētājus, atbilstības novērtēšanas institūcijas u.c.).

Ar standartizācijas procesa organizēšanu un standartu pieņemšanu nacionālā līmen̄̄ nodarbojas nacionālās standartizācijas institūcijas. 
STANDARTIZĀCIJA

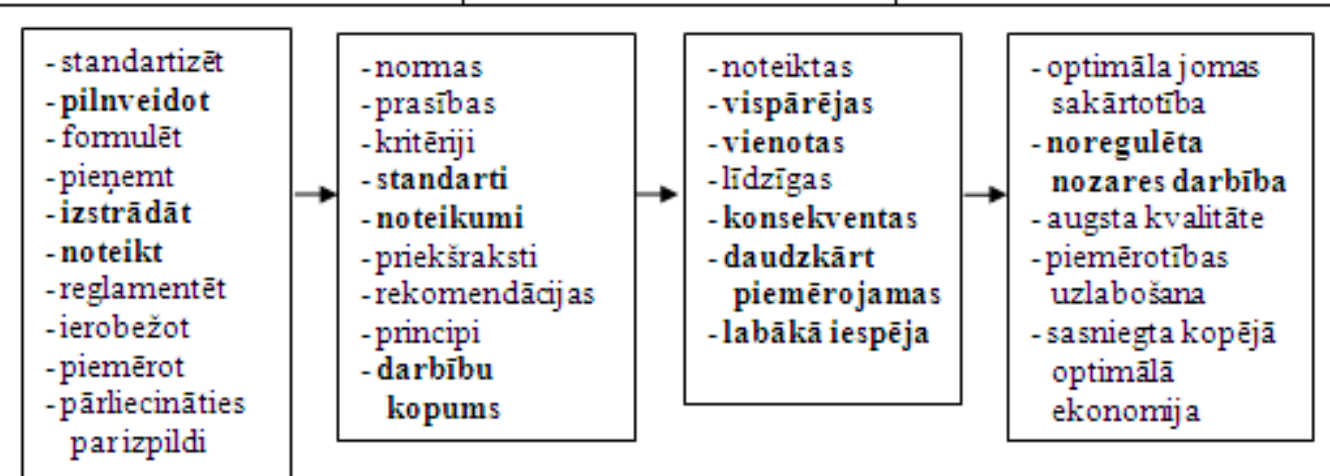

11.att. Ar jēdzienu ‘standartizācija' saistīto terminu kopsakarības shēma.

Autori izvērtējuši ar jēdzienu 'standartizācija' saistītās definīcijas un attēlojuši tajās lietoto terminu kopsakarības shēmu (skat. 11.attēlu).

Secināts, ka standartizācijas procesā ietilpst dažādas darbības, kuru rezultātā tiek panākta pušu vienošanās par prasībām produktam. Izstrādātajam dokumentam (standartam) jābūt daudzkārt piemērojamam, noteiktam, vispārējam, vienotam, konsekventam, tātad optimālākajam no risinājumiem konkrētajā vidē.

Standartu pieņemšanas process daļēji ir līdzīgs normatīvo aktu pieņemšanas procesam. Standartus gan nacionālā, gan starptautiskā līmen̄i izstrādā iesaistītās puses uz kopējas vienošanās jeb konsensus pamata. „Konsensus nozīmē, ka visas iesaistîtās puses standarta tekstu atzīst par pieņemamu un jebkādas domstarpības tiek atrisinātas pirms standarta teksta galīgās apstiprināšanas." [26] Lai starptautiskie standarti būtu saistoši nacionālā līmen̄̄, tie tiek adaptēti nacionālo standartu statusā.

Autori izvērtējuši dažādas termina 'standarts' definīcijas. „Standartizācijas likumā” ietverta l’oti vispusīga definīcija: „Standarts ir attiecīgas institūcijas apstiprināts dokuments, kurš izstrādāts, pamatojoties uz kopēju vienošanos, ietver vispārīgus un daudzkārt piemērojamus noteikumus, norādījumus vai dažāāu veidu darbību vai to rezultātu raksturojumu un kura mērḳis ir optimāli sakārtot noteiktu jomu." [24] 80. gadu sākumā N.Kozlovska un A.Vinogradova apgalvojums [25] bija atbilstošs, ar jūtamu uzsvaru uz standartizāciju kā obligātu normu. Latvijas autori (A.Klauss u.c.) saviem definējumiem [14] par pamatu n̦ēmuši šo definīciju.

Jēdzienu 'standarts' vispusīgi raksturo S.R.Vilsona viedoklis: „Standarts ir dokuments, ko apstiprinājusi atzīta institūcija, kura iesaka brīvprātīgus noteikumus un vadlīnijas, kas aptver produktu, procesu vai metožu raksturojumus." [27] Šis viedoklis ietver būtiskus standartizācijas procesa elementus: kas ir standarts, kas apstiprina standartu, kādā veidā piemērojams standarts un kādas normas tajā ietvertas.

Balstoties uz termina 'standarts' definīciju izvērtējumu, autori piedāvā pilnveidot esošo definīciju šādā redakcijā: „Standarts ir dokuments, kas ietver terminologijiu, prasības un darbības nosacījumus un ko apstiprina atbildīgā institūcija, ar mērķi veicināt noteiktas jomas attīstību." Autori pilnveidojuši esošo definīciju, uzsverot, ka standartā ietvertās informācijas kopuma nozīmīgākās dạ̦as ir termini, prasības un darbību nosacījumi, kā arī noteikts standarta pieņemšanas mērķis, uzskatot, ka ar jomas sakārtošanu vien nepietiek, nepieciešams veicināt arī jomas attīstību.

Ar standartu pielietošanu un atšķirīibām to reglamentācijā autori piedāvā iepazīties 12.attēlā.

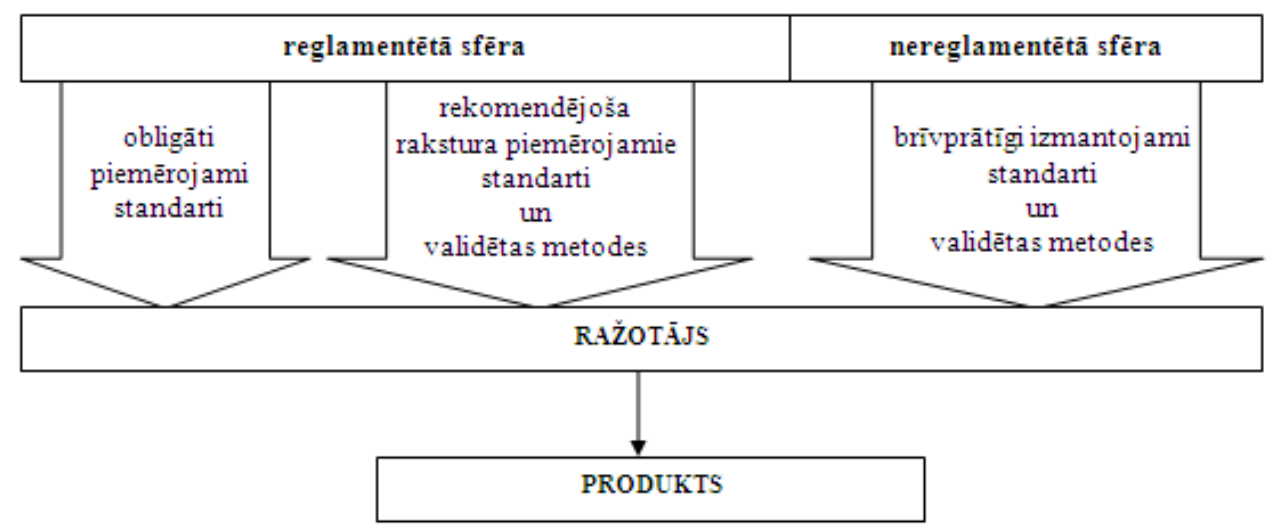

12.att. Standartu pielietošana. 
Nozīmīgs solis standartu veicināšanā bija ES lēmums par Jauno pieeju, kas noteica, ka normatīvie akti satur tikai būtiskās prasības, tehniskās prasības ietverot piemērojamos standartos.

Jautājums, kas saistīts ar produktiem izvirzīto prasību detalizācijas pakāpi un tehnolog̣isko risinājumu harmonizāciju, risināšanai novirzīts starptautiskajām standartizācijas organizācijām. Jaunās pieejas būtisko prasību nodrošināšanai tiek ieteikti piemērojamie standarti. Ražotājam tie nav jāpiemēro obligāti. Vina uzdevums ir nodrošināt produkta atbilstību būtiskajām prasībām, un veidu, kā to nodrošināt, viņš var izvēlēties pats.

Līdz ar Jaunās pieejas spēkā stāšanos un ievērojot tās būtisko atšksirību standartizācijas jomā no Vecās pieejas, izpratne par piemērojamo standartu piemērošanu ražošanas un atbilstības novērtēšanas procesā mūsdienās ir nedaudz apgrūtināta, jo uzṇēmēju un sabiedrības vidū aizvien pastāv viedoklis, ka standarti ir obligāti.

Tādējādi ar Jaunās pieejas pieņemšanu tika ieviests jauns termins 'harmonized standard'. Latviešu valodā nav noteikts vienots šî termina tulkojums un definējums, līdz ar to izpratne par to un tā pielietojumu atšķiras. Latviski šo terminu tulko dažādi: 'piemērojamais standarts', 'saskaņotais standarts' un 'harmonizētais standarts'. Lai piedāvātu termina korektu un atbilstošu tulkojumu latviešu valodā un tā definīciju, autori izvērtēja š̀ jēdziena definīcijas, kas vairāk uzskatāmas kā informatīvs materiāls par tēmu. Rezultātā autori secina, ka anglu valodas terminam 'harmonized standard' atbilstošākais tulkojums latviešu valodā ir 'piemērojamais standarts'. Šāds risinājums piedāvāts, jo šie standarti netiek harmonizēti vai saskaņoti, bet tiek piedāvāta iespēja tos piemērot (pielietot) normatīvajos aktos noteikto būtisko prasību izpildes nodrošināšanai.

Autori ierosina šādu termina 'piemērojamais standarts' defin̄iciju: „Piemērojamais standarts ir nacionālais standarts vai adaptēts starptautiskais standarts, ko var brīvprātīgi piemērot būtisko prasību izpildei konkrētā jomā un par kuru noteiktā kārtībā attiecīgās institūcijas informē sabiedrību." Š̄̄ definīcija ir daudz lakoniskāka nekā ES normatīvajos aktos ietvertā un piemērota atbilstoši Latvijas situācijai standartizācijas jomā, vienlaikus akcentējot brīvprātības principa ievērošanu šo standartu piemērošanā. Autori uzskata, ka šo definīciju nepieciešams ietvert „Standartizācijas likumā̄". Normatīvajos aktos nepieciešams noteikt arī kārtību, kādā institūcijas informē sabiedrību par piemērojamajiem standartiem konkrētās jomās.

\section{c. Metrologija}

Metrologija sevī ietver gan teorētiskos, gan praktiskos mērīšanas aspektus. Balstoties uz veiktajiem mērījumiem, iespējams novērtēt konkrētu produktu atbilstību tiem izvirzītajām prasībām. Mērījumi ir vitāli nepieciešami, lai izvērtētu produktu atbilstību tiem izvirzītajām prasībām, lai kontrolētu, vai process notiek atbilstoši plānotajam, lai novērtētu sasniegtos rezultātus, lai izvērtētu tālākās pilnveides iespējas un plānotu jaunus produktus vai pilnveidotu esošos u.c.

Jēdzienam 'metrologija' ir vairākas definīcijas. Piemēram, P.J.Pots norādījis, ka metrolog̣ija ir zinātne par mērījumiem un to piemērošanu dažādās jomās [28]. K.D.Somers, S.C.Čapels un M.Košeks uzskata, ka metroloǵija ir zinātne par mērījumiem, kas atzarojusies gan no eksperimentālās, gan teorētiskās noteiktības katrā nenoteiktības līmen̄i jebkurā zinātnes un tehnologiijas nozarē [29]. Katrā no minētajām definīcijām raksturota metrologija salīdzinoši šaurā veidā. Autori uzskata, ka visprecīzāk terminu 'metrologiija' raksturo plašāk izmantotā un vienkāršākā definīcija, ko noteicis Starptautiskais reglamentētās metrologijas birojs (Bureau Internationalde Metrologie Legale) - „Metrologija ir zinātne par mērīšanu" [30]. Definīcijā lakoniski ietverta termina būtība - metrologija ir viss, kas saistīts ar mērījumiem.

Balstoties uz dažādos literatūras avotos ietverto definīciju un apgalvojumu izvērtējumu, autori attēlojuši ar jēdzienu 'metrologija' saistīto terminu kopumu (skat. 13. attēlu).

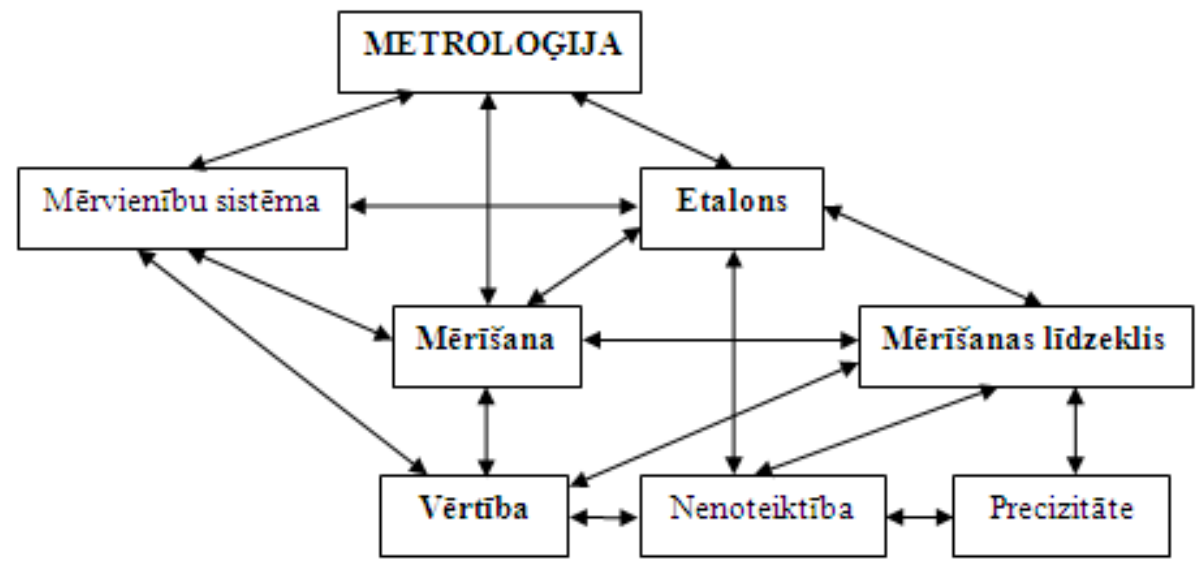

13.att. Ar jēdzienu 'metrologija' saistīto terminu kopsakarības shēma.

No šo terminu kopuma autori secina, ka, lai izteiktu mērījumu vērtības, sabiedrība tās saprastu un mērījumu rezultātus varētu starptautiski atzìt, nepieciešama vienota mērvien̄̄bu sistēma ar noteiktām mērvienībām un fizikālajām kopsakarībām. Lai nodrošinātu mērījumu ticamību, to izsekojamību un varētu pārliecināties par mērījumu precizitāti, 
$2013 / 24$

nepieciešams veikt mērīšanas līdzekḷu un darba etalonu salīdzināšanu ar augstāka līmeņa etaloniem.

P.Krosbijs norādījis, ka mērīšana visbiežāk tiek definēta kā references etalona vai parauga lietošana, to salīdzinot ar citu etalonu [31].

Veicot mērījumu, tiek iegūta konkrēta vērtība. Tomēr iegūtais lielums nav viennozīmīgs, jo, ņemot vērā etalona vai mērī̌sanas līdzekḷa precizitāti, iegūtajai vērtībai iespējama nenoteiktība. Precīzāki mērījumi iespējami dažāda veida mērījumu veikšanai. Daļa sabiedrības uzskata, ka precīzāki mērījumi vienmēr nodrošinās labāku produktu. Praksē tas tā ir ne vienmēr. Mērījumu precizitāte ir nozīmīga arī tirdzniecībā, jo, pamatojoties uz veiktajiem mērījumiem, tiek aprēķināta maksa par produktu. Tādēḷ ir l̦oti būtiski, lai mērījumi būtu precīzi un uzticami.

Vienlaikus autori vēlas norādīt uz problēmu, kas nereti saistīta ar termina 'measuring instrument' tulkojumu latviešu valodā. Praksē konstatēts, ka šis termins latviešu valodā tiek tulkots dažādi: mērīšanas līdzeklis, mērlīdzeklis, mērinstruments, mērīšanas instruments, mēriekārta. Visbiežāk tiek lietoti divi termina tulkojumi latviešu valodā: 'mērīšanas līdzeklis' un 'mērinstruments'.

Sākotnēji tika lietots termins 'mērīšanas līdzeklis', kura definīcija noteikta ar likumu „Par mērījumu vienotību”: „Mērīšanas līdzeklis ir ierīce, kura paredzēta mērījumu veikšanai patstāvīgi vai kopā ar papildu ierīcēm." [17] Diskusijas par termina 'mērinstruments' izmantošanu aktualizējās 2006.gadā, kad spēkā stājās ES normatīvais akts, kura nosaukums angḷu valodā bija - 'Directive on measuring instruments'. Tajā ietvertā definīcija ir loti vispārīga: „Mērinstruments ir jebkura ierīce vai sistēma, kuras mērfunkcija ir minēta 1. un 3. Pantā.” [32]

Lai noteiktu piemērotāko termina tulkojumu, nepieciešams salīdzināt terminus 'līdzeklis' un 'instruments'. Tos salīdzinot, autori secina, ka jēdziens 'līdzeklis' ir salīdzinoši plašāks un tas sevī ietvert terminu 'instruments'. Izvērtējot šo abu terminu pielietojumu, konstatēts, ka termins 'līdzeklis' tiek lietots saistībā ar mērījumu veikšanu. Līdz ar to logisks secinājums, ka arī turpmāk jālieto termins 'mērīšanas līdzeklis'. Autori uzskata, ka nozari koordinējošo un uzraugošo institūciju pārstāvjiem vajadzētu pievērst vairāk uzmanības korektai terminologijas lietošanai un veicināt termina 'mērīšanas līdzeklis' korektu lietojumu.

\section{SECINĀJUMI}

Viena no problēmām atbilstības novērtēšanas jomā ir saistīta ar zinātniskās literatūras trūkumu. Jomas profesionāḷi galvenokārt vadās no normatīvajos aktos, standartos un starptautisko organizāciju vadlīnijās noteiktajiem terminu definējumiem. Tādēl autori uzskata, ka nepieciešams nopietni strādāt pie pētîjumiem un publikācijām latviešu valodā atbilstības novērtēšanas jomā, lai veicinātu uznēēēju un sabiedrības izpratni, kā arī vienotas un korektas terminologijas lietošanu.

Precīzs jēdzienu tulkojums un definējums latviešu valodā ir priekšnosacījums sekmīgai uzṇēmējdarbībai un attīstībai starp Latvijas uzṇēmumiem. Tulkojumam jābūt pārdomātam, atbilstošam jomas specifikai un lietošanas mērķim. Definīcijām jābūt tādām, lai nepārprotami varētu saprast ar jēdzienu apzīmēto darbību kopumu. Izpratnes trūkums var netiešā veidā ietekmēt produktu, jo projektēšanas un ražošanas stadijā var netikt ņemti vērā visi iespējamie produkta kvalitāti ietekmējošie aspekti. Īpaši nozīmīgi tas ir situācijā, kad tiek novērtēta produkta atbilstība tam izvirzītajām prasībām.

Autori izvērtēja ar atbilstības novērtēšanu saistītos jēdzienus, to definīcijas un saistītos apgalvojumus, lai nepieciešamības gadījumā piedāvātu jaunas defin̄icijas vai pilnveidotu esošās, izveidojot vienotu un saskaņotu jēdzienu kopumu, kas atbilstu mūsdienu izpratnei par atbilstības novērtēšanu.

Pētījuma rezultātā secināts, ka nepieciešams pilnveidot terminu 'atbilstība', 'novērtēšana' un 'atbilstības novērtēšana' definīcijas atbilstoši mūsdienu izpratnei par atbilstības novērtēšanu:

- Atbilstība ir fakts, ka objekts (produkts u.c.) izpilda tam noteiktās prasības;

- Novērtēšana ir process, kurā nosaka objekta (produkta u.c.) saskaņu ar tam noteiktajām prasībām;

- Atbilstības novērtēšana ir process, kurā ar atbilstības novērtēšanas procedūrām tiek novērtēta objekta (produkta, procesa u.c.) atbilstība tam noteiktajām prasībām.

Mainoties atbilstības novērtēšanas principiem no Vecās pieejas uz Jauno pieeju, mainījušās arī atbilstības novērtēšanas ietvaros veicamās darbības - procedūras. Autori konstatējuši, ka ikdienā plaši lietotajam terminam 'atbilstības novērtēšanas procedūra' nav definīcijas. Līdz ar to piedāvājuši šādu definīciju: „Atbilstības novērtēšanas procedūra ir darbība, kuras ietvaros tiek novērtēta objekta (produkta, procesa u.c.) atbilstība noteiktajām prasībām un pieñemts lēmums par apliecinājuma izsniegšanu un/vai marķējuma piestiprināšanu."

Secināts, ka termini, definīcijas un apgalvojumi, kas raksturo atbilstības novērtēšanas procedūras (inspicēšanu, sertificēšanu, kalibrēšanu un testēšanu) pilnībā atbilst termina 'atbilstības novērtēšana' definējumam. Lai veicinātu pareizu sabiedrības izpratni par atbilstības novērtēšanas procedūrām, to savstarpējo sakarību un mijiedarbību, autori noskaidrojuši savstarpējo kopsakarību starp dažādām atbilstības novērtēšanas procedūrām, vienlaikus precizējot, kāda veida procedūra ir katra no tām:

- sertificēšana ir nodrošināšanas procedūra;

- inspicēšana ir novērtēšanas/uzraudzības procedūra;

- kalibrēšana un testēšana ir atbalsta procedūras.

Pēc autoru domām, nav lietderīgi noteikt definīciju katram no Jaunās pieejas atbilstības novērtēšanas moduliem. Tie ir pietiekami sarežǵīti, lai noteiktu plašāku skaidrojumu, neaprobežojoties tikai ar definīciju.

Veicot atbilstības novērtēšanas elementu un ar to saistīto jēdzienu izvērtējumu, autori konstatēja, ka dažiem no jēdzieniem nav noteikts vienots tulkojums latviešu valodā.

Latviešu valodā atbilstošākais termina tulkojums būtu 'paziņotā institūcija' ('notifed body'). Un autori ierosina šādu definīciju: „Paziņotā institūcija ir akreditēta atbilstības novērtēšanas institūcija, par kuras kompetenci darboties 
noteiktā jomā atbildīgā institūcija informējusi Eiropas Komisiju." Darbība, kuras rezultātā atbilstības novērtēšanas institūcijas tiek paziņotas Eiropas Komisijai un citām dalībvalstīm, lai tās atzītu par paziṇotajām institūcijām, korekti būtu saucama par 'notifikāciju'.

Izvērtējot jautājumus, kas saistīti ar standartizāciju un šì termina definīcijas, autori secināja, ka esošās definīcijas ir nepiln̄̄gas un pilnībā neraksturo mūsdienīgu standartizācijas procesu, kā rezultātā piedāvāta pilnveidota termina 'standartizācija' definīcija: „Standartizācija ir process, kurā iesaistītās puses nosaka prasības un kārtību, kas ir labākā iespēja, lai noregulētu noteiktas jomas darbību."

Pêtījuma rezultātā autori konstatējuši, ka termina harmonized Standard atbilstošākais tulkojums latviešu valodā būtu 'piemērojamais standarts', kuram piedāvāta arī definīcija: „Piemērojamais standarts ir nacionālais standarts vai adaptēts starptautiskais standarts, ko var brīvprātīgi piemērot būtisko prasību izpildei konkrētā jomā un par kuru noteiktā kārtībā attiecīgās institūcijas informē sabiedrību."

Veicot terminu un to definīciju izvērtējumu metroloǵijas jomā, autori secina, ka arī turpmāk lietojams termins 'mērīšanas līdzeklis' ('measuring instrument') un nav pamata to mainīt ar citu terminu.

Autori uzskata, ka atbilstoši veiktajam pētījumam un sniegtajiem priekšlikumiem nepieciešams precizēt nacionālos normatīvos aktus. Nozari koordinējošo un uzraugošo institūciju pārstāvjiem jāpievērš vairāk uzmanības un jāveicina korekta terminologijas lietošana.

\section{LITERATŪRAS SARAKSTS}

[1] J.R. Evans, W.M. Lindsay, The Management and Control of Quality Third edition. NewYork: West Publishing company, 1996.pp.767.

[2] Uzñēmējdarbības loğistikas terminu anglu - latviešu vārdnīca. Rīga: Zvaigzne ABC, 2007. 168.lpp.

[3] English - Latvian dictionary of international business. Rīga: Zvaigzne ABC, 2006. pp.704.

[4] Macmillan English dictionary for advanced learners. Second edition. International student edition. Macmillan, 2007. pp.1747.

[5] Longman Dictionary of Contemporary English. The living dictionary. Longman, 2003. pp.1949.

[6] Eiropas Parlamenta un Padomes lēmums Nr.768/2008/EK 2008.gada 9.jūlijs par produktu tirdzniecības vienotu sistēmu un ar ko atcel Padomes lēmumu Nr.93/456/EK [tiešsaiste]. [skatīts 10.09.2012.]. Pieejams:

http://eurlex.europa.eu/LexUriServ/LexUriServ.do?uri=OJ:L:2008:218:0082:012 $8: \mathrm{LV}: \mathrm{PDF}$

[7] LVS EN ISO/IEC 17000: 2005 Atbilstības novērtēšana - Vārdnīca un vispārīgie principi

[8] Druķis P. Jaunā un globālā pieeja., Rīga: SIA „Personāla sertifikācijas institūts", 2003. 85.lpp.

[9] Strawbridge G. What is conformity assessment ? ISO Bulletin, 2002. October, pp.3.

[10] Kvalitătes terminu vārdnīca. Rīga: KIF „Biznesa komplekss”, 2003. 63.lpp.

[11] Biznesa leksikas skaidrojošā vārdnīca. Anglu - latviešu, Rīga: Avots, 2003. 1084.lpp

[12] Likums "Par atbilstības novērtēšanu" [tiešsaiste]. Rīga: Saeima [skatīts 15.11.2012.]. Pieejams: http://www.likumi.lv/doc.php?id=63836.

[13] M. Rurāne, Ražošana. Rīga: Turības mācību centrs, 1998. 122.lpp.

[14] A. Klauss, Zinības vadītājam. Rīga: Preses nams, 2002. 560.lpp.

[15] M. Rurāne, Uznēēèjdarbības organizācija un plānošana. Rīga: Biznesa augstskola Turība, 2002. 330.lpp.
[16] Zinātnes un tehnologijijas vārdnīca. Rīga: Telia Latvija, Norden AB, 2001. 754.1pp.

[17] Likums "Par mērījumu vienotību" [tiešsaiste]. Rīga: Saeima [skatīts 29.10.2012.]. Pieejams: http://www.likumi.lv/doc.php?id=42562.

[18] R. Liepinana, I. Lapina, J. Mazais, Role of Conformity Assessment in Global Market. In: Conference Practice and Research in Private and Public Sector - 2012. Vilnius, Lithuania, April 26-27, 2012. Proceedings. pp.453.-461.

[19] J. Mikelsons, I. Goba, Akreditācija. Rīga: SIA "Personāla sertifikācijas institūts", 2004. 42.lpp.

[20] Ilustrētā svešvārrdu vārdnīca. Rīga: Avots, 2005. 891.lpp.

[21] A, Zuckerman. EU trends could prove costly to Americans business, Quality Progress, 1998, January. pp.49.

[22] Eiropas Parlamenta un Padomes regula (EK) Nr.765/2008 2008.gada 9.jūlijs ar ko nosaka akreditācijas un tirgus uzraudzības prasības attiecībā uz produktu tirdzniecību un atcel regulu (EEK) Nr.339/93 [tiešsaiste]. [skatīts 29.09.2012.]. Pieejams: http://eurlex.europa.eu/LexUriServ/LexUriServ.do?uri=OJ:L:2008:218:0030:004 7:LV:PDF

[23] M. Rostovska, Nepārtikas prečzinība. Rīga: Biznesa augstskola Turība, 2003. 234.lpp.

[24] Standartizācijas likums [tiešsaiste]. Rīga: Saeima [skatīts 10.10.2012.]. Pieejams: http://www.likumi.lv/doc.php?id=50425

[25] N. Kozlovskis, A. Vinogradovs, Standartizācijas pamati, pielaides, sēžas un tehniskie mērījumi. Rīga: Zvaigzne, 1982. 400.lpp.

[26] D.R. Arter, The Standards Development Process. Quality Progress, 1999, July, pp.65.-69.

[27] S.R. Wilson, The Impact of Standards on Industrial Development and Trade. Quality Progress, 1999, July, pp.71.-75.

[28] P.J. Potts, Glossary of Analytical and Metrological Terms from the International Vocabulary of Metrology (2008). Geostandards and Geoanalytical Research, 2012, pp.1.-16.

[29] K.D. Sommer, Chappel, S.C., Kochsiek, M. Calibration and verification: Two procedures having comparable objectives and results. OIML Bulletin, 2001, XLII (1), pp.5.-12.

[30] Vocabulary of Terms in Legal Metrology OIML. Paris: Bureau International de Metrologie Legale International, 2000. pp.28.

[31] P. Crosby, Quality Improvement through defect prevention. The individual's role. Florida: Philip Crosby Associates Inc., 1985, pp.231.

[32] Eiropas Parlamenta un Padomes direktīva 2004/22/EK 2004.gada 31.marts par mērinstrumentiem [tiešsaiste]. [skatîts 20.12.2012.]. Pieejams: http://eurlex.europa.eu/LexUriServ/LexUriServ.do?uri=CONSLEG:2004L0022:2 0070101:LV:PDF

Raimonda Liepina, Mg.oec., Lecturer of Riga Technical University, Faculty of Engineering Economics and Management, the Department of Quality Technologies. Almost 10 year experience as Head of Conformity Assessment Coordination Division in the Internal Market Department of the Ministry of Economics of the Republic of Latvia. Area of research interests: quality management, conformity assessment, among them standardization, accreditation, metrology and approaches of technical harmonisation.

Raimonda.Liepina@rtu.lv

Jānis Mazais, Dr.sc.ing., Professor at Riga Technical University, Faculty of Engineering Economics and Management, the Department of Quality Technologies. More than 30 years working at Riga Technical University in different scientific and academic positions. Ten year experience working with the United Nations Development Programme in capacity of Operations Manager. Area of research interests: Quality and Process Management and Improvement.

Janis.Mazais@rtu.lv

Inga Lapina, Dr.oec., Associate Professor, working at Faculty of Engineering Economics and Management of Riga Technical University since 1997. In 2011 she joined the Institute for Quality Engineering at Riga Technical University as an Acting Head of the Department of Quality Technology. Area of research interests: quality management, business ethics and corporate social responsibility, macroeconomics and development of human capital. Working as an expert of Evaluation Commission at Higher Education Quality Evaluation Centre in Latvia.

Inga.Lapina@rtu.lv 
Raimonda Liepiṇa, Jānis Mazais, Inga Lapiṇa. The Components of Conformity Assessment: Related Concepts, their Improvement

The purpose of the research is to evaluate terms and improve definitions related to conformity assessment for development of a unified totality of terminology in this field in Latvian language. In order to make analysis, different qualitative research methods, including assessment, analysis and comparison were used by applying inductive and deductive methodologies. As the main sources for research were used books, publications, national and international laws and regulations, standards and other binding documents applicable to the field of conformity assessment. The terms and definitions related to conformity assessment and its components (accreditation, certification and metrology) are evaluated with a purpose to improve the current definitions or to suggest the new ones, thus developing unified and coordinated totality of the terms which corresponds to contemporary understanding of conformity assessment. One reason of the conformity assessment related problems is insufficient number of scientific publications in Latvian. On the basis of assessment of the terms the authors proposed updated translation of the terms 'notified body' and 'harmonized standard', as well as, substantiated application of the term 'measuring instrument' in Latvian. As a result of the research the authors worked out proposals for improvement of definitions in Latvian for the terms 'conformity', 'assessment', 'conformity assessment' and 'standardization' and developed new definitions for the terms 'conformity assessment procedure', 'notified body' and 'harmonized standard'. In order to facilitate proper understanding by all involved parties about conformity assessment procedures an explanation of the essence for each procedure is developed. The results of the research will facilitate better comprehension about placement of goods into the market, thus diminishing a possibility to place into the market and to use unsafe goods.

Раймонда Лиепиня, Янис Мазайс, Инга Лапиня. Элементы оценки соответствия: связанные понятия, их совершенствование

Цель исследования - дать оценку существующим терминам в области оценки соответствия и совершенствовать их дефиниции для создания единой совокупности терминов на латышском языке. Использованы качественные методы исследования, в том числе оценивание, анализ и сопоставление, применяя индуктивный и дедуктивный методы. В качестве источников информации исследования использованы книги и научные публикации, международные и национальные нормативные акты, стандарты и другие соответствующие документы, относящиеся к области оценки соответствия. Проведено оценивание понятий и их дефиниций, относящихся к оценке соответствия и ее элементам (аккредитации, стандартизации и метрологии) с целью предложить новые дефиниции или усовершенствовать существующие, таким образом создавая единую и согласованную совокупность терминов на латышском языке, соответствующую современному пониманию об оценке соответствия. Недостаточное общественное понимание сферы оценки соответствия связано с ограниченным числом публикаций в этой области на латышском языке.Основываясь на проведенном исследовании, уточнен перевод на латышский язык терминов 'обьявленная институция' ('notified body') и 'применяемый стандарт' ('harmonized standard'), а также обосновано применение термина 'средство измерения' ('measuring instrument'). В результате исследования предложено усовершенствовать дефиниции терминов 'соответствие', 'оценка', 'оценка соответствия' и 'стандартизация', а также разработаны дефиниции для терминов 'процедура оценки соответствия', 'объявленное учреждение' и 'применяемый стандарт' на латышском языке. Для того, чтобы способствовать пониманию заинтересованными сторонами процедур оценки соответствия, проведено оценивание каждой из них. Благодаря проведенному исследованию, повысится общий уровень понимания в рассматриваемой области и снизится возможность поставки на рынок и потребления опасных продуктов. 